\title{
The Effect of Calcium-Silicate Cements on Reparative Dentinogenesis Following Direct Pulp Capping on Animal Models
}

\author{
Mihai Andrei ${ }^{1}$, Raluca Paula Vacaru ${ }^{1}$, Anca Coricovac ${ }^{1}$, Radu Ilinca ${ }^{2}$, Andreea Cristiana Didilescu ${ }^{1, *}$ (D \\ and Ioana Demetrescu ${ }^{3,4}$ iD
}

1 Division of Embryology, Faculty of Dental Medicine, Carol Davila University of Medicine and Pharmacy, 8 Eroii Sanitari Boulevard, 050474 Bucharest, Romania; mihai.andrei@umfcd.ro (M.A.); raluca.vacaru@umfcd.ro (R.P.V.); anca.coricovac@umfcd.ro (A.C.)

2 Division of Biophysics, Faculty of Dental Medicine, Carol Davila University of Medicine and Pharmacy, 8 Eroii Sanitari Boulevard, 050474 Bucharest, Romania; radu.ilinca@umfcd.ro

3 Department of General Chemistry, University Politehnica Bucharest, Spl. Independentei 313, 060042 Bucharest, Romania; I_demetrescu@chim.upb.ro

4 Academy of Romanian Scientists, 3 Ilfov, 050044 Bucharest, Romania

* Correspondence: andreea.didilescu@umfcd.ro; Tel.: +40-722536798

\section{check for} updates

Citation: Andrei, M.; Vacaru, R.P.; Coricovac, A.; Ilinca, R.; Didilescu, A.C.; Demetrescu, I. The Effect of Calcium-Silicate Cements on Reparative Dentinogenesis Following Direct Pulp Capping on Animal Models. Molecules 2021, 26, 2725. https://doi.org/10.3390/molecules 26092725

Academic Editor: Alejandro Rodríguez Pascual

Received: 12 April 2021

Accepted: 3 May 2021

Published: 6 May 2021

Publisher's Note: MDPI stays neutral with regard to jurisdictional claims in published maps and institutional affiliations.

Copyright: (c) 2021 by the authors. Licensee MDPI, Basel, Switzerland. This article is an open access article distributed under the terms and conditions of the Creative Commons Attribution (CC BY) license (https:/ / creativecommons.org/licenses/by/ $4.0 /)$.

\begin{abstract}
Dental pulp vitality is a desideratum for preserving the health and functionality of the tooth. In certain clinical situations that lead to pulp exposure, bioactive agents are used in direct pulpcapping procedures to stimulate the dentin-pulp complex and activate reparative dentinogenesis. Hydraulic calcium-silicate cements, derived from Portland cement, can induce the formation of a new dentin bridge at the interface between the biomaterial and the dental pulp. Odontoblasts are molecularly activated, and, if necessary, undifferentiated stem cells in the dental pulp can differentiate into odontoblasts. An extensive review of literature was conducted on MedLine/PubMed database to evaluate the histological outcomes of direct pulp capping with hydraulic calcium-silicate cements performed on animal models. Overall, irrespective of their physico-chemical properties and the molecular mechanisms involved in pulp healing, the effects of cements on tertiary dentin formation and pulp vitality preservation were positive. Histological examinations showed different degrees of dental pulp inflammatory response and complete/incomplete dentin bridge formation during the pulp healing process at different follow-up periods. Calcium silicate materials have the ability to induce reparative dentinogenesis when applied over exposed pulps, with different behaviors, as related to the animal model used, pulpal inflammatory responses, and quality of dentin bridges.
\end{abstract}

Keywords: biomaterials; direct pulp capping; dental pulp; dentin bridge; calcium-silicate cements

\section{Introduction}

Dental pulp vitality preservation is a necessity for prolonging a tooth's life in the oral cavity. Dental pulp can be directly exposed in an oral environment as a result of deep carious lesions caused by cariogenic microorganisms, traumatic injuries or iatrogenic factors that can lead to bacterial infiltration, inflammation and infection [1,2]. Maintaining pulp vitality is necessary to avoid further complications that can lead to endodontic therapy or tooth extraction [3].

Pulp vitality can be maintained in certain situations by a stimulatory treatment that involves the activation of the dentin-pulp complex so as to produce reparative dentin at the level of the pulpal involvement area. In such situations, dental pulp protection against bacterial infiltration or toxicity of restorative dental materials, and dentin layer healing can be achieved by direct pulp capping (DPC) procedure, which involves the placement of a pulp-capping agent at the level of exposure [4]. 
Successful DPC consists in maintaining the vitality and functionality of the pulp and in new dentin bridge formation [5]. In addition to the size and depth of exposure, the presence of microorganisms at the site of exposure or the patient's age [6], the type of biomaterial used for DPC plays an important role in the prognosis and success of the procedure $[4,7]$.

\subsection{Molecular Mechanisms in Dentinogenesis}

The dentin-pulp complex is located inside the tooth. Both tissues, dentin and pulp, are embryologically developed from the dental papilla of the neural crest's ectomesenchyme [8]. Dentin is a mineralized connective tissue, harder than the regular bone and less hard than the enamel, consisting mainly of calcium hydroxyapatite $\left(\mathrm{Ca}_{10}\left(\mathrm{PO}_{4}\right)_{6}(\mathrm{OH})_{2}\right)$ and a collagenous matrix [9]. The pulp is a soft connective tissue that contains different cells such as odontoblasts, fibroblasts and undifferentiated mesenchymal cells [10], located in the pulp chamber and in the root canal, being isolated and protected from external factors by dentin, which surrounds it. Besides sensory, nutritional and defensive roles [11], dental pulp's prime function is to secrete dentin due to the external odontoblastic cell layer [12].

During odontogenesis and up until the end of apexogenesis, primary dentin is formed, representing the majority of the circumpulpal dentine matrix [9]. Secondary dentin is formed in physiological conditions by continuous deposition of dentin after root development is completed, throughout life, as long as the tooth preserves its vitality [13]. Although slightly different, both primary and secondary dentin have regular, tubular structures comprising of intertubular and peritubular dentin. Tertiary dentin, a more dystrophic, sometimes atubular matrix, is formed specifically at the pulp-dentin interface following different pathological processes, either carious or traumatic. The intensity of the environmental stimuli may vary and produce two types of tertiary dentin. In response to a mild stimulus (e.g., slowly progressing caries), post-mitotic odontoblast cells are preserved and stimulated to secrete reactionary dentin [14]. If the stimulus is stronger (e.g., rapidly progressing deep caries, tooth cavity preparation or traumatic injury), the odontoblast cells are destroyed, and a much complex process is generated, which involves mitosis, chemotaxis, migration, adhesion and differentiation of mesenchymal stem cells to form a new generation of odontoblast-like cells, which will eventually secrete reparative dentin [15]. These cells may originate from the immune system, subodontoblastic cell layer, or from pulp fibroblasts, and their origin may influence the cell phenotype and further cellular interactions $[14,16,17]$.

The differences regarding the morphology of the tubular structure of the three types of dentine are thought to be due to molecular substrate [15]. In fact, dentin is a reservoir of bioactive molecules, such as growth factors, neurotrophic factors, neuropeptides and cytokines, sequestered in extracellular matrix during dentinogenesis and that can be solubilized in pathological conditions: carious, traumatic or iatrogenic [18]. These bioactive molecules are signaling molecules that lead to receptor phosphorylation and modulate several signaling transduction pathways after binding, essential for dentinogenesis being MAPK (mitogen-activated protein kinase) and PI3K/AKT/mTOR (phosphatidylinositol 3-kinase/protein kinase B/mechanistic target of rapamycin), pathways that are engaged in cell proliferation, adhesion, migration and apoptosis. Among the MAPK family, p38 MAPK has the pivotal role of activating odontoblast's secretory activity and is involved in repair and regeneration processes [18,19].

Vital pulp therapies and pulp-capping materials enhance biological responses and favor tertiary dentinogenesis by stimulating odontoblast's secretory activity; therefore, further research is needed to understand specific molecular mechanisms and how to use them therapeutically.

\subsection{Calcium-Silicate Biomaterials as Pulp Capping Agents}

A variety of biomaterials have been proposed and developed over time for pulpcapping procedures. Pulp-capping materials must ensure pulp regeneration and induce the 
formation of a hard tissue barrier following odontoblasts' activation. Materials such as calcium hydroxide (CH) [20,21], zinc oxide eugenol cement [22], resin-modified glass-ionomer cement [23], MTA [24,25], adhesive systems [26], enamel matrix derivative [27], collagen [28], formocresol [29] and hydroxyapatite [30] have been proposed as pulp-capping agents over time.

In addition to the nature of the pulpal insult, the prognosis of success in pulp capping is greatly influenced by the type of pulp-capping agent used. An ideal pulp-capping material has to present biocompatibility, good adhesion to the dental hard tissues, compatibility with the restoration materials it comes in contact with, good marginal sealing, insolubility in tissue fluids, easy handling and manipulating, short setting time, proper mechanical properties, radiopacity, antimicrobial activity and possibly low cost [31,32].

In the past, formocresol has been an agent of choice for pulp therapy, with very controversial results, due to its cytotoxic, genotoxic and carcinogenetic effects [33]. Zinc oxide eugenol cement has also been proposed as a pulp-capping agent, but its effectiveness is questionable, especially because of eugenol's high cytotoxicity and interfacial leakage [34,35]. Although eugenol is considered to have antibacterial properties, which might have been considered as an advantage of this material, it has been observed that its availability diminishes dramatically within time [36]. Furthermore, in human studies, it showed chronic pulpal inflammation and lack of healing or dentin bridge formation [37], as opposed to $\mathrm{CH}$.

$\mathrm{CH}$ has been the gold standard for several decades since its introduction in 1921 [38], but its shortcomings such as lack of adhesion to dentin or resin restorations, poor mechanical properties, bacterial infiltration, tunnel defects in dentin bridges and pulpal resorption [39-41] led to the choice of clinicians towards new, much more elaborate materials such as MTA and later, materials derived from MTA: calcium silicate, calcium phosphates or calcium aluminate-based materials.

These biomaterials are hydraulic calcium-silicate cements that are derived from the original PC, and their composition is detailed in Figure 1. PC and MTA have similar compositions, while the other materials are modified or hybrid materials for mechanical and biological improvements. Due to their bioactivity, they can provide a much better dentin bridge formation than $\mathrm{CH}$ and a lower degree of pulpal inflammation [42]. The setting reaction known as hydration is a chemical reaction that involves the major compounds in dissolution and precipitation processes, resulting in different hydrates. This reaction can occur in wet environments. The setting reaction implies the reaction of calcium silicate with water forming calcium-silicate hydrate and calcium hydroxide [43].

\subsection{Portland Cement (PC)}

PC is the most common cement of general use and a basic ingredient of concrete. PC is composed of lime, silica, alumina, ferric oxide and other compounds [44]. PC has the following major phases: dicalcium and tricalcium silicate (as major constituents), tricalcium aluminate and tetracalcium aluminoferrite [45]. Compared to similar conventional dental materials, PC does not contain radiopacifying agents. PC also contains arsenic, which raises major concerns regarding its use due to its possible toxic effects [46]. However, arsenic levels are low and vary depending on the type of PC [47,48]. With this respect, the amount of arsenic released is not a reason for its contraindication [49].

Given the low cost of PC and the fact that it has an almost identical composition to MTA [50] and similar antibacterial effects [51], it can be considered a more economical alternative. In various studies, ordinary PC has been modified with different compounds: bismuth oxide, iodoform or zirconium oxide for radiopacification [52]; calcium chloride, which decreased the setting time, maintained the $\mathrm{pH}$ at high values, decreased solubility and reduced the quantity of water necessary for mixing, therefore, lowering the material's permeability [53]; $\mathrm{CH}$ for antibacterial activity [45]. However, these changes in the material's composition can affect the physico-chemical properties and bioactivity of the cement. 


\subsection{Mineral Trioxide Aggregate (MTA)}

MTA was introduced in 1993 [54]. Initially, MTA was introduced as an endodontic material for root filling treatment, as it offered the possibility of apexification in immature teeth for apical barrier formation or repairment of various defects, such as perforations or fenestrations $[55,56]$. The bioactivity of the material promotes stimulation and regeneration at the level of the dentin-pulp complex, making it suitable as a pulp-capping agent. Initial grey MTA was replaced by white MTA in 2004 for aesthetic considerations, as it lacked in tetracalcium aluminoferrite, therefore, having a lower iron oxide content [57]. MTA is presented as a fine powder that is mixed with water. Usually, the ingredients come in pre-dosed packages. In terms of micro- and macroscopic properties, MTA is almost identical to PC. MTA is mainly composed of Portland type I cement with the main phases of tricalcium and dicalcium silicate, tricalcium aluminate, tricalcium and silicate oxides, and bismuth oxide as a radiopacifying agent. Depending on the manufacturer, the setting reaction can vary from a long time ( $2.5 \mathrm{~h}$ in the case of ProRoot MTA) to a much shorter time (15 min in the case of MTA Angelus) [57]. Even if MTA remains the most representative hydraulic calcium-silicate cement in its class, drawbacks, such as prolonged setting time, which requires more treatment sessions, high cost and difficult handling [58], lead to the release of derivate materials. New modified materials based on calcium silicates have been formulated over time in response to the disadvantages of MTA, but also in order to improve the pulpal response.

\subsection{TheraCal LC}

One MTA derivative material designed for direct or indirect pulp capping is TheraCal LC (Bisco, Schaumburg, IL, USA), which is a light-cured resin-modified tricalcium-silicate material released in 2011. TheraCal LC contains mineral compounds (type III PC), radiopaque agent (barium zirconate), hydrophilic thickening agent (fumed silica) and resins (bis-phenyl glycidyl methacrylate and polyethylene glycol dimethacrylate) $[59,60]$. The setting reaction is based on light curing for $20 \mathrm{~s}$ for each layer of applied material. As hydraulic cement, it depends on the water up taken from the dentin moisture and its diffusion within the material. The advantages of this material compared to MTA are its short setting time, leading to fewer treatment sessions, easy maneuverability and handling. Being a resin-based material, which does not require any conditioning of the dentin surface, TheraCal LC can be bonded with various types of adhesives after application [61]. In vitro studies showed a very low cytompatibility of TheraCal LC [62] due to the fact that resinbased materials exhibited toxic effects on cultured odontoblast-like cells [63]. This risk was associated with the residual unpolymerized resin components that remained in contact with pulp tissue, monomers such as BisGMA, HEMA, TEGDMA, and UDMA being cited as having the lowest biocompatibility $[64,65]$. In the last five years, nanoparticles, such as carbonic nanomaterials, hydroxyapatite, silica, iron and titanium oxide, zirconia, have been used in dental materials, such as TheraCal LC, to enhance their physical, chemical, and biological properties [66].

\subsection{Biodentine}

Biodentine (Septodont, Saint-Maur-des-Fossés, France) is a tricalcium-silicate cement developed as a dentin substitute. Biodentine is a powder-liquid system. The powder has the following main phases: tricalcium silicate, dicalcium silicate, calcium carbonate and zirconium dioxide as radiopacifier [67]. The liquid consists of calcium chloride. After mixing the components, the setting time takes up to $12 \mathrm{~min}$ for the cement to harden [68]. Compared to $\mathrm{CH}$, Biodentine has lower porosity, better mechanical strength and less solubility. The dentin bridges show no tunnel defects, having a better sealing ability. Biodentine can be used as a temporary enamel substitute for up to 6 months and, without any surface treatment, could be a permanent dentin substitute [69]. In the literature [70], Biodentine's behavior is presented as a favorable repair material based on its biocompatibility assigned 
to hydroxyapatite crystals' deposition on the surface, which is in direct contact with tissue fluids [71].

\subsection{Bioceramic-Based Materials}

Initially developed for various other purposes, such as joint replacements, blood vessel prostheses or heart valves, they had been promoted as efficient and biocompatible endodontic materials, with high success rates [72]. Endodontic bioceramics are not influenced by humidity or blood contamination [73,74], are stable and insoluble over time, providing an adequate seal [75]. Before setting, bioceramics manifest an antibacterial effect, and afterwards, they become biocompatible and bioactive [76]. Among these bioceramic endodontic materials, we can mention BioAggregate (Innovative Bioceramix, Vancouver, BC, Canada), with a composition similar to that of MTA's. Its composition consists of tricalcium silicate, calcium phosphate and silicon dioxide and tantalum oxide as a radiopacifier [67]. BioAggregate consists of $\mathrm{Ca}, \mathrm{Si}$ and $\mathrm{O}$, with a lower content of $\mathrm{Al}$ and lack of heavy element contamination [77]. BioAggregate can promote adhesion, migration, attachment [78], odontoblasts' differentiation [79] and mineralization by activating the MAPK pathway of the human dental pulp cells [80].

\subsection{Premixed Materials}

A series of premixed or ready-to-use materials have been developed; this category includes iRoot BP Plus (also known as EndoSequence root repair material/EERM; Innovative BioCeramix, Vancouver, BC, Canada), TotalFill BC RRM (FKG Dentaire SA, La Chaux-deFonds, Switzerland) or Endocem MTA (Maruchi, Wonju, Korea). Their advantage is that they have a uniform consistency, are not technique sensitive and lack waste [81]. Premixed bioceramics require moisture from the environment in order to harden.

iRoot BP Plus is a premix bioceramic thick/putty white paste material, radiopaque, composed of tricalcium silicate, zirconium oxide, tantalum pentoxide, dicalcium silicate, calcium sulfate, calcium phosphate monobasic and filler agents, aluminum-free, insoluble [67], which requires water to harden and does not shrink during setting, with excellent physical properties [82]. During the setting reaction, when it comes in contact with water and/or moisture, it produces $\mathrm{CH}$ [82]. iRoot BP plus is a biocompatible material with antibacterial properties capable of inducing new dentin bridge formation when applied as a DPC agent [83].

TotalFill BC RRM (root repair material) is a calcium-silicate-based material for root canal repair and filling material. TotalFill BC RRM is available in three consistencies: injectable paste, putty and malleable putty. According to the manufacturer, TotalFill BC RRM consists of tricalcium silicate, dicalcium silicate, zirconium oxide, tantalum pentoxide and anhydrous calcium sulfate. The material has a very good radiopacity and an adequate setting time [84]. However, the material showed less marginal adaptation and sealing ability when compared to ProRoot MTA [85].

Endocem MTA is an MTA-derived material for endodontic use. Endocem MTA's composition consists of calcium oxide, aluminum oxide, silicate oxide, magnesium oxide and bismuth oxide [86]. Endocem MTA has a number of advantages such as a faster setting time than conventional MTA and a better washout resistance [87], less tooth discoloration than MTA [88], a low cytotoxicity effect for preosteoblastic cells [89], calcium release and the ability to form apatite-like structures [90].

These bio-inductive materials, based on calcium silicates, can be used in different endodontic procedures, depending on the nature of each material and its purpose: apexification and apexogenesis, root perforations repair, as direct and indirect pulp-capping agents, in pulpotomy or pulpectomy procedures, regenerative procedures and as root filling materials [67].

The purpose of this review is to highlight the effect of calcium-silicate cements in reparative dentinogenesis, providing a better insight on molecular mechanisms on the 
different types of calcium-silicate cements and on histological findings in animal models, following DPC capping with these pulp-capping agents.

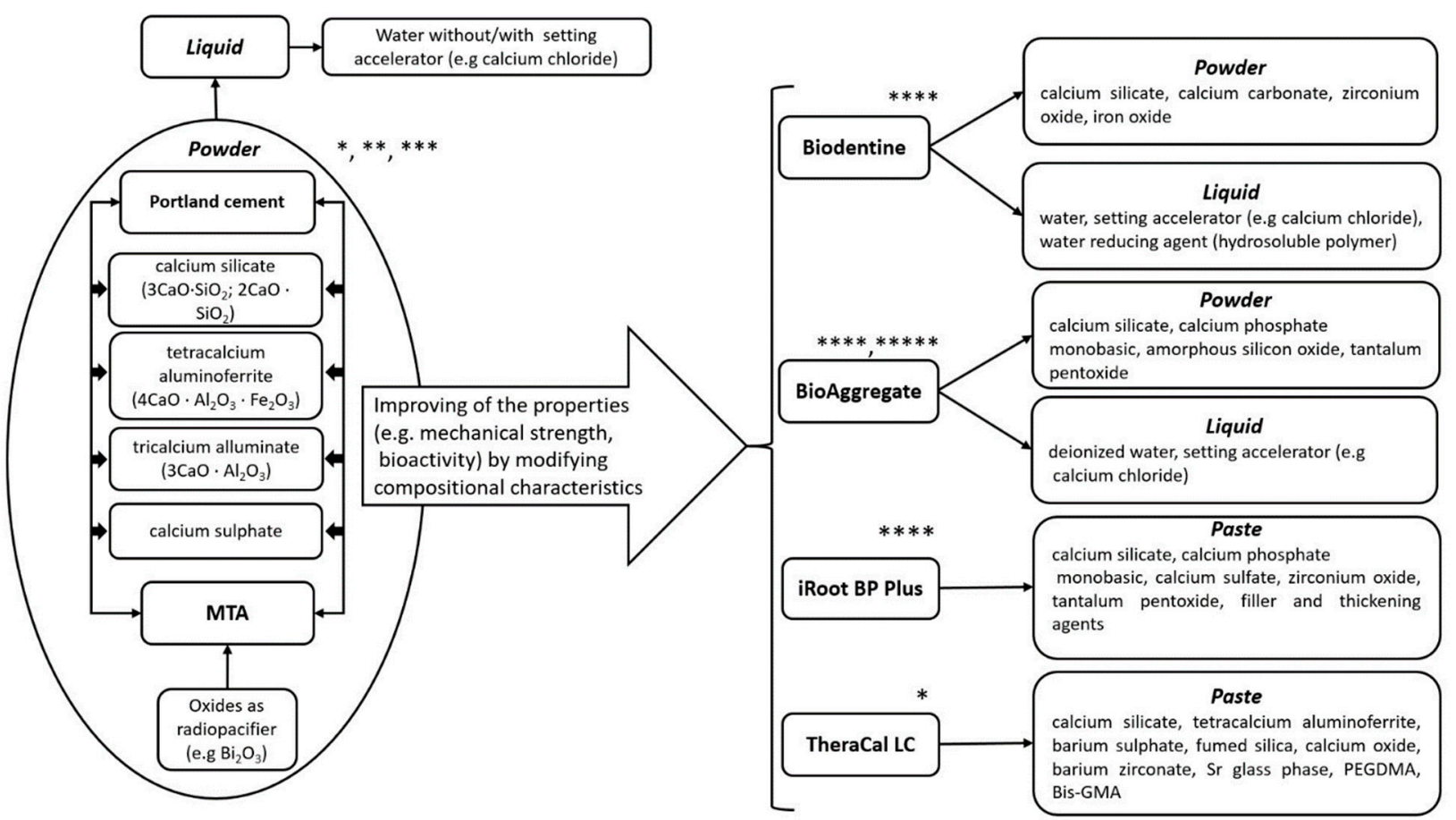

Figure 1. Composition of different calcium-silicate-based materials used as DPC agents. $*^{*}[60],{ }^{* *}[45],{ }^{* * *}[50],{ }^{* * * *}[67]$, ***** [91]).

\section{Histological Findings in Animal Model Following Direct Pulp Capping Procedure Methodology}

We performed an extensive search of the PubMed (Medline) database, limited from 1962 to October 2020, to identify studies that were eligible for the aim of this review. During the screening process, two reviewers (MA and RPV) extracted the data independently, using EndNote X8 and X9 (Clarivate Analytics) for reference management. The search strategy for PubMed used medical subject heading terms and their variations, as shown in Table 1. Case series and reports, letters to the editor, and reviews were excluded manually during the screening process. Reference lists of the included articles were hand-searched in order to identify further eligible studies. Afterwards, full-text articles were assessed for eligibility.

The studies were included if they met the following criteria:

- $\quad$ original scientific studies;

- $\quad$ studies performed on animal subjects;

- $\quad$ studies reporting DPC with hydraulic calcium-silicates cements;

- $\quad$ studies reporting histological assessments, with highlights on inflammatory cell infiltrate, pulp tissue disorganization, reparative dentin formation, quality of reparative dentin, defective area or cell inclusion, the impact of dentin fragments.

We considered a study ineligible for inclusion if any of the following criteria were met:

- $\quad$ case reports, case series, letters to the editor, reviews;

- $\quad$ studies performed in vitro;

- $\quad$ studies that included indirect pulp capping or pulpotomy on animal models;

- $\quad$ non-English language publications.

For each included study the following data were recorded: author, publication year, country, study design, animal species, sample size, follow-up time, intervention, materials used, outcomes assessed and results. 
Table 1. The search strategy for PubMed used medical subject heading terms and their variations.

\begin{tabular}{|c|c|}
\hline & Search Strategy Pubmed Database \\
\hline \#1 & $\begin{array}{l}\text { (((("Animals, Laboratory”[Mesh]) OR “Animals, Laboratory/drug effects”[Mesh]) OR } \\
\text { (animal AND testing)) OR (laboratory animal)) OR (animal AND laboratory) }\end{array}$ \\
\hline \#2 & $\begin{array}{l}\text { ((("Dental Pulp Capping"[Mesh]) OR (Dental Pulp Capping)) OR ("Dental Pulp } \\
\text { Capping/adverse effects"[Mesh])) OR (((("Dental Pulp Exposure"[Mesh]) OR “Dental Pulp } \\
\text { Exposure/drug therapy"[Mesh]) OR “Dental Pulp Exposure/physiopathology"[Mesh]) OR } \\
\text { "Dental Pulp Exposure/adverse effects"[Mesh]) OR (dental pulp) }\end{array}$ \\
\hline \#3 & $\begin{array}{c}(((((\text { "Dentinogenesis"[Mesh]) OR “Dentinogenesis/drug effects"[Mesh]) OR } \\
\text { “Dentinogenesis/physiology"[Mesh]) OR (dentinogenesis)) OR (tertiary dentin)) OR (dentin) }\end{array}$ \\
\hline \#4 & $\begin{array}{c}\text { (((((“Histological Techniques/analysis”[Mesh] OR “Histological } \\
\text { Techniques/diagnosis”[Mesh] OR “Histological Techniques/drug effects”[Mesh])) OR } \\
\text { (histologic)) OR (histology)) OR (histocytologic)) }\end{array}$ \\
\hline \#5 & $\begin{array}{c}\text { ((((((((pulp-capping agent[MeSH Terms]) OR ((((“mineral trioxide aggregate” [Supplementary } \\
\text { Concept]) OR “Calcium Compounds"[Mesh]) OR “Calcium Compounds/adverse } \\
\text { effects”[Mesh]) OR “Calcium Compounds/therapeutic use”[Mesh])) OR (MTA cement)) OR } \\
\text { (Aggregate ProRoot)) OR (Tricalcium Silicate)) OR (Biodentine)) OR (“accelerated Portland } \\
\text { cement" [Supplementary Concept])) OR (Portland cement)) OR (MTA) }\end{array}$ \\
\hline \#6 & \#1 AND \#2 AND (\#3 OR \#4) AND \#5 AND (English(Filter)) \\
\hline
\end{tabular}

From the articles included for the review, only the part concerning the histological evaluations following DPC on animal models was selected. Additionally, each study had to involve the use of a pulp-capping agent that is a calcium-silicate-based material, regardless of whether the material was used as a tested material or as a control material. Studies reporting results of pulpotomies or indirect pulp capping were excluded.

\section{Results}

A total of 26 publications were included in this review. The studies were performed on different experimental animals. We have included in our review 13 studies performed on rats or mice (Table 2), 9 studies on dogs (Table 3), 3 studies on minipigs (Table 4) and 1 study on primates (Table 5). The number of animals included in studies varied from 2 to 45, while the number of teeth on which DPC was applied varied from 19 to 128 . All studies compared MTA with other pulp-capping agents, except for one study that compared MTA with MTA enriched with calcium chloride [92], one that did not include MTA in the materials tested [93] and one that did not have a comparison material for MTA [94]. In all selected articles, the pulp chamber was opened by mechanical exposure, using different shaped burs, files, probes or endodontic explorers. The cavities were prepared mainly on maxillary molars, except for one study that performed DPC on incisors [95], two on canines [96,97], one on anterior teeth [98], two on incisors, canines and premolars [92,99], two on incisors, canines, premolars and molars [100,101], one on incisors and molars [102], one on mandibular molars [103] and four did not provide this information [93,104-106]. The cavities performed on molars were primarily class I occlusal cavities, while for the other categories of teeth, class V cavities were prepared mainly on the buccal surface. The pulp exposure diameter varied from $0.4 \mathrm{~mm}$ to $1.5 \mathrm{~mm}$, the majority being between 0.8 and $1 \mathrm{~mm}$ wide. Various restorative materials were used for cavity filling after the placement of the DPC agent, such as self-curing glass-ionomer cement, light-cured glassionomer cement, light-cured dental resin, flowable dental composite, zinc-eugenol oxide intermediate restorative material or silver amalgam. Follow-up periods of time varied among the included studies from a minimum of 7 days to up to 3 months. There were 11 studies $[92,93,95,96,102,104,105,107-110]$ that had only one follow-up evaluation, 10 with two $[97,98,100,101,106,111-115], 3$ with three [99,103,116], 1 with four [117] and 1 with five [94] follow-up evaluations. After the animals were euthanized, the teeth were histologically processed so that they could be analyzed under light microscopy. 
Table 2. Histological evaluation following DPC with calcium-silicate-based materials on rats/mice animal models.

\begin{tabular}{|c|c|c|c|c|}
\hline Publication. & DPC Agent & Animal Type & Teeth Type & Histological Evaluation \\
\hline $\begin{array}{l}\text { Guerrero-Gironés, et al., } \\
2020 \text { [107] }\end{array}$ & $\begin{array}{c}\text { Melatonin } \\
\text { (5 mg, Sigma-Aldrich, St. Louis, } \\
\text { MA, USA) } \\
\text { MTA } \\
\text { (ProRoot MTA, Dentsply } \\
\text { Maillefer, Ballagues, } \\
\text { Switzerland) } \\
\text { MTA and melatonin } \\
\text { Melatonin + melatonin }\end{array}$ & $\begin{array}{l}\text { Sprague } \\
\text { Dawley rats }\end{array}$ & $\begin{array}{l}\text { First and secondary } \\
\text { maxillary molars }\end{array}$ & $\begin{array}{l}\text { - } 30 \text { days follow-up } \\
\text { - } \quad \begin{array}{l}\text { All four groups of MTA, melatonin, MTA and melatonin and melatonin + melatonin } \\
\text { showed vital pulps with a regular odontoblastic layer, lack of necrosis and new } \\
\text { dentin bridge formation. }\end{array} \\
\text { - } \quad \text { Melatonin's dentinogenetic effect was no significantly different from that of MTA. }\end{array}$ \\
\hline Paula, et al., 2020 [103] & $\begin{array}{c}\text { White ProRoot MTA } \\
\text { (Dentsply Tulsa Dental } \\
\text { Specialties, Tulsa, OK, USA) } \\
\text { Biodentine } \\
\text { (Septodont, France) } \\
\text { Positive control group: } \\
\text { Glass ionomer cement } \\
\text { (Ketac Fil Plus Aplicab, 3M } \\
\text { Espe, USA) } \\
\text { Negative control groups } \\
\text { (No intervention performed) }\end{array}$ & Wistar Hun rats & $\begin{array}{c}\text { First } \\
\text { mandibular molars }\end{array}$ & 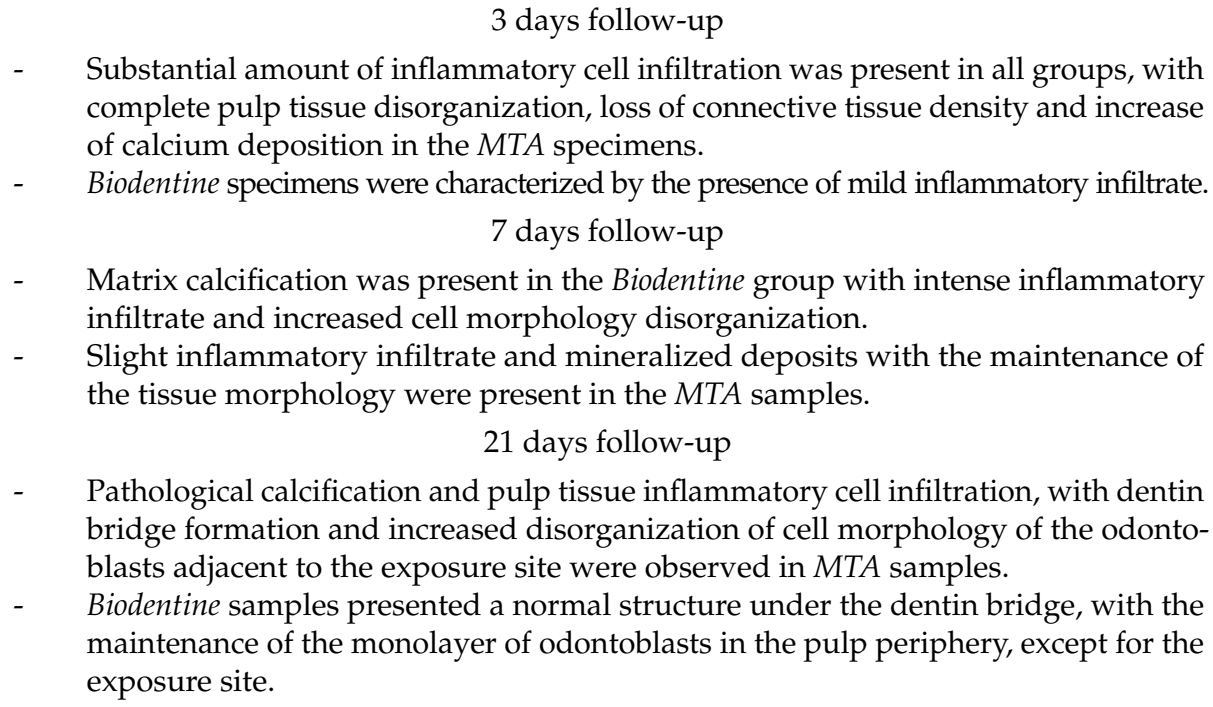 \\
\hline
\end{tabular}


Table 2. Cont.

\begin{tabular}{|c|c|c|c|}
\hline Publication. & DPC Agent & Animal Type & Teeth Type \\
\hline Hanada, et al., 2019 [117] & $\begin{array}{c}\text { Bioactive glass cement* } \\
\text { (Nishika Canal Sealer } \\
\text { BG/NCS-BG; Nippon Shika } \\
\text { Yakunin, Yamaguchi, Japan), } \\
\text { NSY-222-S_-modified } \\
\text { from NCS-BG, } \\
\text { WMTA } \\
\text { (WMTA ProRoot Dentsply, Tulsa } \\
\text { Dental, OK, USA) } \\
\text { CH } \\
\text { (Dycal, Dentsply Caulk } \\
\text { Milford, DE) }\end{array}$ & Wistar Rats & $\begin{array}{l}\text { Maxillary first } \\
\text { molars }\end{array}$ \\
\hline
\end{tabular}

\section{1st day follow-up}

- A mild inflammation and no dentin bridge formation were observed in all groups 4 days follow up

- $\quad$ Signs of slight pulp tissue inflammation were present and of a necrotic layer covering the entire exposed pulp and no signs of new dentin deposition.

$$
7 \text { days follow-up }
$$

- $\quad$ A thin reparative dentin layer was present in all groups, and odontoblast-like cells were distributed with mild inflammation.

$$
14 \text { days follow-up }
$$

- $\quad$ A thick reparative dentin with dentinal tubes was present, with mild inflammation and a decreasing tendency of the necrotic layer.

- $\quad$ All tested materials had a similar response in new hard tissue deposition.

$$
\text { First-day follow-up }
$$

- Regarding the inflammatory response, the two experimental materials had similar behaviors, presenting mild to moderate pulp inflammation with local disruption of the odontoblastic layer.

- A mild to moderate inflammatory response in the positive control group.

- $\quad$ No deposition of reparative dentin was present in any groups.

White ProRoot MTA

(Dentsply Tulsa Dental Specialties, Tulsa, OK, USA) Bio-MA

Trongkij, et al., 2019 [116]

(M-Dent/SCG
Bangkok, Thailand)

Positive control group (uncapped pulp exposure)

Negative control groups (intact teeth)
Maxillary first molars

\section{7 days follow-up}

- Moderate to severe inflammatory pulpal response was present in the positive control group.

- $\quad$ Reduced inflammation in most specimens from both experimental groups with moderate hard tissue deposition, as well as a newly formed mineralized matrix. 30 days follow-up

- Severe inflammatory response was present in the positive control group with moderate hard tissue deposition with non-tubular structure.

- $\quad$ The presence of odontoblasts-like cells could be noticed under the newly deposited hard tissue layer in the Bio-MA and MTA groups.

- $\quad$ Both MTA and Bio-MA induced hard tissue deposition, completely covering the exposed areas, with more than $50 \%$ tubular structure and cell inclusion, with no major differences between them in terms of quantity and quality of reparative dentin deposition.

* All negative control groups displayed no inflammatory signs and intact odontoblastic layer at all follow-up times. 
Table 2. Cont.

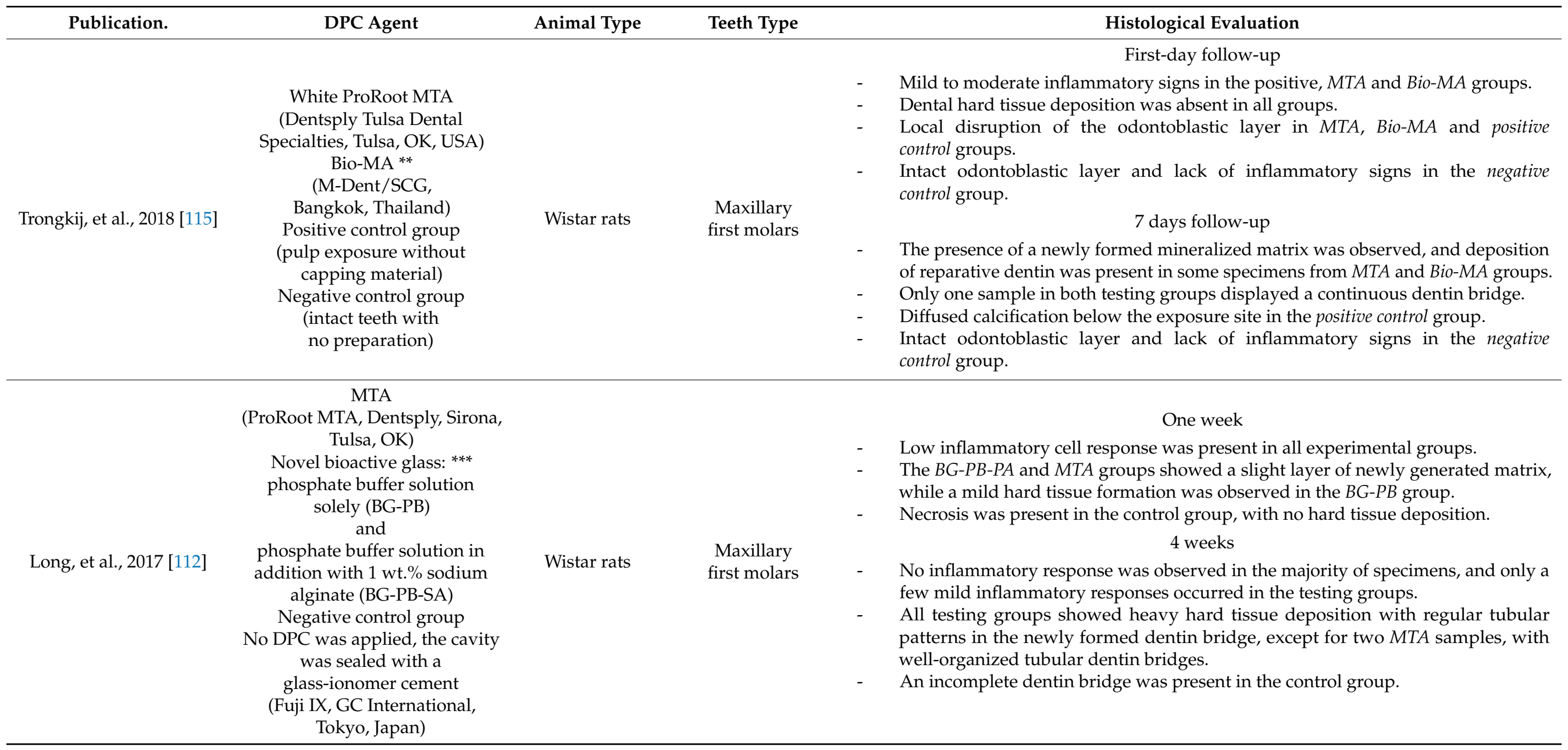


Table 2. Cont.

\begin{tabular}{|c|c|c|c|c|}
\hline Publication. & DPC Agent & Animal Type & Teeth Type & Histological Evaluation \\
\hline Liu, et al., 2015 [111] & $\begin{array}{c}\text { iRoot BP Plus } \\
\text { Innovative BioCeramix, } \\
\text { Vancouver, BC, Canada) } \\
\text { MTA } \\
\text { (Dentsply, Tulsa Dental, Tulsa, } \\
\text { OK, USA) } \\
\text { Glass ionomer cement } \\
\text { (Control group) } \\
\text { (Fuji IX, GC International, } \\
\text { Tokyo, Japan) }\end{array}$ & Wistar rats & $\begin{array}{l}\text { Maxillary } \\
\text { first molars }\end{array}$ & $\begin{array}{l}\text { - } 1 \text { week follow-up } \\
\text { - } \quad \text { A similar inflammatory cell response was present in both iRoot BP Plus and } \\
\text { MTA groups. } \\
\text { Regarding hard tissue deposition, all samples in the } i \text { Root BP Plus group presented } \\
\text { a mild hard tissue deposition, while the MTA group revealed a slight layer of newly } \\
\text { generated matrix adjacent to the material in three-quarters of the specimens. } \\
\text { Mild to moderate inflammatory signs in the control group. } \\
\quad 4 \text { weeks follow-up } \\
\text { - } \\
\text { All iRoot BP Plus specimens and three-quarters of MTA specimens exhibited repar- } \\
\text { ative dentin bridge formation, with a tubular dentin structure and the newly } \\
\text { deposited dentin was connected to the primary dentin. } \\
\text { All specimens from the control group showed necrosis. }\end{array}$ \\
\hline Kim, et al., 2015 [108] & $\begin{array}{c}\text { Endocem Zr } \\
\text { (Maruchi, Wonju, Korea) } \\
\text { MTA } \\
\text { (ProRoot, Dentsply, Tulsa Dental, } \\
\text { Tulsa, OK, USA) } \\
\text { Light-cured } \\
\text { glass-ionomer cement } \\
\text { (Control group) } \\
\text { (Fuji II LC, GC, Tokyo, Japan) }\end{array}$ & Wistar rats & $\begin{array}{l}\text { Maxillary } \\
\text { first molars }\end{array}$ & $\begin{array}{l}\text { 4 weeks follow-up } \\
\text { - } \quad \text { Both Endocem } \mathrm{Zr} \text { and MTA displayed reparative dentin with complete continuity } \\
\text { underneath the pulp-capping materials at four weeks post-treatment, with no } \\
\text { significant differences between the tested materials. } \\
\text { - No hard-tissue presence was found in the control group, where teeth were DPC } \\
\text { capped with a light-cured glassionomer }\end{array}$ \\
\hline Lee, et al., 2014 [109] & $\begin{array}{c}\alpha \text {-tricalcium phosphate-based } \\
\text { ( } \alpha \text {-TCP; Mediclus, } \\
\text { Cheongju, Korea) } \\
\text { MTA } \\
\text { (ProRoot MTA, Dentsply, Tulsa } \\
\text { Dental, Tulsa, OK, USA) } \\
\text { Light-cured glass-ionomer } \\
\text { cement (control group) } \\
\text { (Fuji II LC; GC, Tokyo, Japan) }\end{array}$ & Wistar rats & $\begin{array}{l}\text { Maxillary } \\
\text { first molars }\end{array}$ & $\begin{array}{l}\text { - } 4 \text { weeks follow-up } \\
\text { - Tertiary dentin with complete continuity was formed underneath the pulp-capping } \\
\text { agent in both testing groups. Odontoblasts-like cells were polarized and arranged } \\
\text { in a palisade pattern. } \\
\text { - No hard tissue deposition was found in the control group. } \\
\text { - There were no significant differences between the two tested groups }(\alpha-T C P \\
\text { and MTA). }\end{array}$ \\
\hline
\end{tabular}


Table 2. Cont.

\begin{tabular}{|c|c|c|c|c|}
\hline Publication. & DPC Agent & Animal Type & Teeth Type & Histological Evaluation \\
\hline $\begin{array}{l}\text { Moazzami, et al., } \\
2014 \text { [113] }\end{array}$ & $\begin{array}{c}\text { Odontoblastic } \\
\text { differentiating material } \\
\left(\text { ODM) }{ }^{* * * *}\right. \\
\text { MTA } \\
\text { (ProRoot MTA, Dentsply, Tulsa } \\
\text { Dental, Tulsa, OK, USA) } \\
2 \text { control groups: teeth DPC with } \\
\text { ODM without active ingredient } \\
\text { and with a light-cured } \\
\text { glass-ionomer cement (GC } \\
\text { International, Tokyo, Japan) }\end{array}$ & $\begin{array}{c}\text { Sprague } \\
\text { Dawley } \\
\text { rats }\end{array}$ & Maxillary molars & $\begin{array}{l}\text { 2 weeks follow-up } \\
\text { - } \quad \text { All specimens in the MTA group had vital pulps and, in some samples, mild } \\
\text { inflammatory responses were present. } \\
\text { The ODM group presented a more intense inflammatory reaction, and only } 80 \% \text { of } \\
\text { the pulps were vital. } \\
\text { - } \text { Odontoblastic differentiation and reparative dentin formation were present in the } \\
\text { ODM and MTA groups. } \\
\text { All specimens from both control groups were necrotic with no odontoblastic differ- } \\
\text { entiation or hard tissue deposition. } \\
\quad 2 \text { months follow-up } \\
\text { - Odontoblastic differentiation and reparative dentin deposition occurred in both } \\
\text { groups with a maximum mean thickness of the dentin in the ODM group, where } \\
\text { most of the pulps were vital, with partial necrosis beneath the capping site. } \\
\text { A well-organized tubular dentin bridge with predentin and the odontoblastic layer } \\
\text { was present in } M T A \text { and ODM specimens on the floor of the pulp chambers. }\end{array}$ \\
\hline Park, et al., 2014 [110] & $\begin{array}{c}\text { Endocem } \\
\text { (Maruchi, Wonju, Korea) } \\
\text { MTA } \\
\text { (ProRoot, Dentsply, Tulsa Dental, } \\
\text { Tulsa, OK, USA) } \\
\text { Light-cured } \\
\text { glass-ionomer cement } \\
\text { Control group } \\
\text { (Fuji II LC, GC, Tokyo, Japan) }\end{array}$ & Rats & $\begin{array}{l}\text { Maxillary } \\
\text { first molars }\end{array}$ & $\begin{array}{l}\text { 4 weeks follow-up } \\
\text { - The histological evaluation showed tertiary dentin formation with complete conti- } \\
\text { nuity beneath the pulp-capping agent in both testing groups, with no inflammatory } \\
\text { or a mild inflammatory pulp tissue response. } \\
\text { - } \quad \text { Odontoblasts-like cells were present and arranged in a palisade pattern. } \\
\text { - In the control group, there was no presence of tertiary dentin deposition. }\end{array}$ \\
\hline
\end{tabular}


Table 2. Cont.

\section{Publication.}

DPC Agent
Animal Type Teeth Type

\section{Histological Evaluation}

1st day follow-up

- $\quad$ A thin necrotic layer and a few inflammatory cells at the exposure site were present.

3 days follow-up

- A slight to mild inflammation response was present.

5 days follow-up

\section{WMTA}

Kuratate, et al., 2008 [94] ～(white ProRoot MTA, Dentsply

Tulsa Dental, Tulsa, OK)

Maxillary

first molars
- New matrix formation was present at the exposure site.

7 days follow-up

- A thin calcified bridge adjacent to the exposure site being observed in all samples. 14 days follow-up

- $\quad$ Dentin bridge formation with a tubular structure was present in all samples with odontoblasts-like cells.

\section{2 weeks follow-up}

\section{MTA}

(ProRoot MTA, Dentsply, Tulsa

Dental, Tulsa, OK, USA)

Light-cured resin

Control group

(Point4, Kerr Hawe,

Bioggio, Switzerland)
Maxillary

first molars
Mice

Simon, et al., 2008 [114

- A line with a high affinity for histological dye following the material contour was observed in the MTA group.

\section{5 weeks follow-up}

- $\quad$ Samples from the control group showed normal pulp tissue with no inflammatory signs and lack of dentin bridge formation.

- $\quad$ New dentin bridge formation was present in all specimens from the MTA group and dentinal tubes with non-linear and interrupted trajectory could be observed in the matrix of the dentin bridges of three specimens.

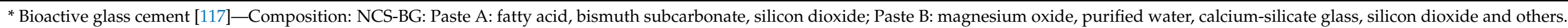

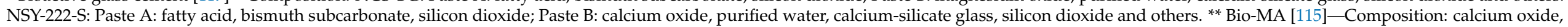

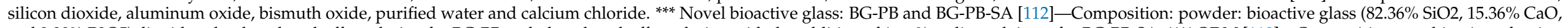

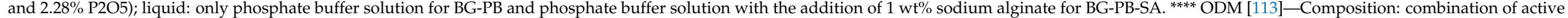

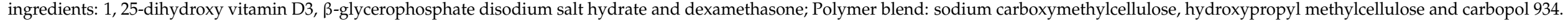


Table 3. Histological evaluation following DPC with calcium-silicate-based materials on dog animal model.

\begin{tabular}{|c|c|c|c|c|}
\hline Publication. & DPC Agent & Animal Type & Teeth Type & Histological Evaluation \\
\hline $\begin{array}{l}\text { Zaen El-Din, et al., } \\
2020 \text { [98] }\end{array}$ & $\begin{array}{c}\text { MTA } \\
\text { (ProRoot White MTA, } \\
\text { Dentsply, Sirona) } \\
\text { Biodentine } \\
\text { (Septodont, } \\
\text { Saint-Maur-des-Fossés, France) } \\
\text { Nano-hydroxyapatite } \\
\text { (nHAP)* } \\
\text { CH } \\
\text { (Dycal, Dentply } \\
\text { Sirona Endodontics) }\end{array}$ & Dogs & Anterior teeth & $\begin{array}{l}\text { - } 7 \text { days follow-up } \\
\text { - In the } C H \text {, Biodentine and MTA groups, there were mild signs of pulp inflammation, } \\
\text { with partial pulp necrosis in some specimens and early signs of calcifications in } \\
\text { one-third of samples. Some specimens showed partial tissue necrosis. } \\
\text { The } n H A P \text { group presented mild to none inflammatory pulpal tissue response, with } \\
\text { partial tissue necrosis or early signs of mineralization in some samples. } \\
\quad 3 \text { months follow-up } \\
\text { - } \\
\text { Moderate inflammation was present in half samples of the } C H \text { group, while in } \\
\text { the MTA, Biodentine and } n H A P \text { groups, pulp inflammation was absent or mild } \\
\text { in two-thirds of the specimens, with tissue necrosis extended in some } M T A \text { and } \\
\text { Biodentine samples. } \\
\text { Regarding hard tissue formation, in the MTA and Biodentine groups there were two- } \\
\text { thirds of specimens with complete calcified dentin bridge, in the } C H \text { group, there } \\
\text { were some samples with complete and more samples with interrupted calcified } \\
\text { dentin bridge. } \\
\text { In the } n H A P \text { group, there were samples with both continuous and interrupted } \\
\text { dentin bridges and a few samples with scattered calcific formations. }\end{array}$ \\
\hline Akhavan, et al., 2017 [99] & $\begin{array}{l}\text { MTA (ProRoot MTA, Dentsply, } \\
\text { Sirona, Tulsa, OK), } \\
\text { Dentin adhesives: } \\
\text { Clearfil S3/CS3, Bond (Kuraray, } \\
\text { Osaka, Japan); Optibond } \\
\text { (FL/OBF, Kerr, Orange, } \\
\text { CA, USA); } \\
\text { Single Bond/SB, (3M, ESPE, MN, } \\
\text { USA); Clearfil SE/CSE Bond } \\
\text { (Kuraray, Tokyo, Japan) } \\
\text { CH } \\
\text { (Dycal, Dentsply, Germany) }\end{array}$ & Dogs & $\begin{array}{l}\text { Premolars, canines, } \\
\text { first, second and } \\
\text { third incisors }\end{array}$ & $\begin{array}{l}\text { - CSE and OBF induced necrosis in one, respectively two specimens, while } S B \text { and } \\
\text { - } \quad \text { Inflammation was present in the OBF group in four samples, while SB induced } \\
\text { stimulated odontoblastic generation. } \\
\quad 21 \text { days follow-up } \\
\text { - } \quad \text { Inflammation was present in } 4 \text { samples from the OBF group. } \\
\text { - } \quad 63 \text { stimulated odontoblastic layer formation in } 4 \text { samples. } \\
\text { - } \quad \text { MTA specimens had the lowest inflammatory response, odontoblastic layer forma- } \\
\text { tion and the highest amount of hard tissue deposition. }\end{array}$ \\
\hline
\end{tabular}


Table 3. Cont.

\section{Publication.}

MTA

(Endocem Maruchi, Korea)
Port Cal **
$\mathrm{PC}$
Dogs

with $20 \%$ bismuth oxide
Negm, et al., 2017 [106]
Animal Type Teeth Type

\section{Histological Evaluation}

\section{3 weeks follow-up}

- None of the three silicate-calcium-based materials presented new dentin bridge formation Port Cal specimens exhibited a continuous odontoblastic layer same as PC with $20 \%$ bismuth oxide group.

- $\quad$ MTA samples showed destruction of the odontoblastic layer near the exposure site and some areas of superficial necrosis.

$$
3 \text { months follow-up }
$$

- $\quad$ All groups had partial and complete new dentin bridge formation with the presence of a continuous odontoblastic layer.

- Port Cal specimens displayed partial and complete dentin bridge formation, continuous odontoblastic layer and minimal inflammatory signs.

- $\quad$ The PC with $20 \%$ bismuth oxide specimens showed the highest inflammation cell count, with complete or incomplete new dentin bridge formation.

- MTA samples exhibited the highest scores for dentin bridge formation with the regularity of the pulp tissue architecture, with normal pulp and continuous odontoblastic layer.
iRoot BP Plus

(Innovative BioCeramix

Vancouver, BC, Canada)

MTA

Beagle dogs

Shi, et al., 2016 [95]

(ProRoot MTA, Dentsply, Tulsa

Dental, Tulsa, OK, USA)
BCAp ***

(biomimetic carbonated apatite)

$$
\text { MTA }
$$

Danesh, et al., 2012 [97]

\section{3 months follow-up}

- Calcified bridge formation at the interface of pulp exposure could be observed in most of the specimens from both groups, with regular or irregular dentinal tubes pattern and dentin chips presence in some specimens.

- $\quad$ One MTA specimen had connective tissue in the dentin bridge.
(ProRoot MTA, Dentsply, Tuls
Dental, Tulsa, OK, USA)

\section{7 days follow-up}

MTA and BCAp groups had all pulps vital.

Some MTA samples with no complete dentin tissue formation.

$B C A p$ samples with neither complete nor incomplete hard tissue bridges formation, with lateral deposition of hard tissue in 4 specimens.

$$
70 \text { days follow-up }
$$

- $\quad$ All pulps from both groups were vital.

- $\quad$ None of the specimens in the BCAp group presented new dentin bridge formation

6 specimens from the MTA group six had complete or incomplete hard tissue bridges, with mild or lack of pulp tissue inflammation. The bridges were thinly composed of dentin or irregular hard tissue. 
Table 3. Cont.

\begin{tabular}{|c|c|c|c|c|}
\hline Publication. & DPC Agent & Animal Type & Teeth Type & Histological Evaluation \\
\hline Parirokh, et al., 2011 [92] & $\begin{array}{c}\text { MTA } \\
\text { (ProRoot MTA, Dentsply, Tulsa } \\
\text { Dental, Tulsa, OK, USA) } \\
\text { MTA } \\
\text { With addition of } \\
\text { calcium chloride }\end{array}$ & Dogs & $\begin{array}{l}\text { Lateral incisor, } \\
\text { canines and } \\
\text { premolars }\end{array}$ & $\begin{array}{l}2 \text { months follow-up } \\
\text { - } \quad \text { There were insignificant differences between the two groups, with no acute inflammation. } \\
\text { - }\end{array}$ \\
\hline Asgary, et al., 2008 [96] & $\begin{array}{c}\text { MTA } \\
\text { (ProRoot MTA, Dentsply, Tulsa } \\
\text { Dental, Tulsa, OK, USA) } \\
\text { CH } \\
\text { (Dycal, LD Caulk, Milford, DE) } \\
\text { NEC }^{* * * *} \\
\text { (Novel endodontic cement) }\end{array}$ & Beagle dogs & Canines & $\begin{array}{l}\text { 8 weeks follow-up } \\
\text { - The } C H \text { group presented all pulps vital, pulp necrosis in two specimens and no } \\
\text { complete calcified bridge formation. } \\
\text { - All samples from both } M T A \text { and NEC groups had vital pulps with no sign of } \\
\text { inflammatory response; complete dentin bridge formation was observed in } 75 \% \text { of } \\
\text { the specimens. } \\
\text { - The NEC group had a slightly better well-organized odontoblast-like cell layer and } \\
\text { a sufficient thickness of the dentinal bridge. }\end{array}$ \\
\hline Briso, et al., 2006 [104] & $\begin{array}{c}\text { MTA } \\
\text { (ProRoot MTA, Dentsply, Tulsa } \\
\text { Dental, Tulsa, OK, USA) } \\
\text { CH } \\
\text { (Reagen, Quimibras, Rio de } \\
\text { Janeiro, Brazil) }\end{array}$ & Mongrel dogs & $\mathrm{N} / \mathrm{A}$ & $\begin{array}{l}\quad 60 \text { days follow-up } \\
\text { - } \quad \text { In the MTA group, there were more specimens with complete and incomplete } \\
\text { dental bridge formation than in the } C H \text { group. } \\
\text { - There were fewer specimens in the MTA group with inflammatory cell response } \\
\text { and necrosis. } \\
\text { - The dentin bridge morphology was better in the MTA specimens with bridges } \\
\text { composed of dentin associated or not to areas of irregular hard tissue deposition. } \\
\text { - } \quad \text { MTA specimens exhibited thicker hard tissue brides than } C H \text {. }\end{array}$ \\
\hline $\begin{array}{c}\text { Faraco and Holland, } \\
2001 \text { [105] }\end{array}$ & $\begin{array}{c}\text { MTA } \\
\text { (Dentsply Tulsa, Tulsa, } \\
\text { OK, USA) } \\
\text { CH } \\
\text { (Dycal, L.D. Caulk, Milford, DE) }\end{array}$ & Dogs & $\mathrm{N} / \mathrm{A}$ & $\begin{array}{l}\text { - } 2 \text { months follow-up } \\
\text { - } \quad \text { MTA group had obviously better results than the } C H \text { group in terms of new hard } \\
\text { tissue formation. } \\
\text { All MTA specimens exhibited hard tissue bridges with tubular dentin, while } C H \\
\text { specimens presented a lower number of the newly formed structures. } \\
\text { - The inflammatory pulp response was also better in the } M T A \text { group, while chronic } \\
\text { inflammatory response and severe neutrophilic infiltrate were present in several } \\
\text { cases in the } C H \text { group. } \\
\text { Absence of inflammatory infiltrate and microorganisms in the } M T A \text { samples. }\end{array}$ \\
\hline
\end{tabular}

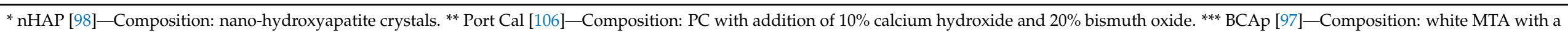

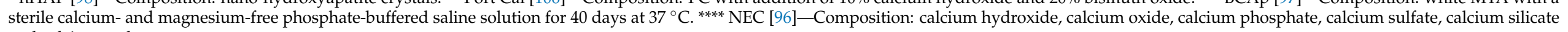
and calcium carbonate. 
Table 4. Histological evaluation following DPC with calcium-silicate-based materials on pig animal model.

\section{Publication.} DPC Agent
Animal Type Teeth Type

MTA

(ProRoot MTA, Dentsply, Sirona

Tulsa, OK, USA)

TheraCal LC

Li, et al., 2018 [100]

(Bisco, Schaumburg, IL, USA)

TCS 50

\section{Gottingen Incisors, canines} minipigs premolars
and molars

\section{Histological Evaluation}

\section{7 days follow-up}

- Regarding the inflammatory response, all three materials showed similar behavior TCS50 presented a well-organized exposed pulp tissue, with no inflammatory signs in the deeper pulp area and a normal odontoblastic layer.

- No hard tissue deposition was observed in any of the groups.

$$
70 \text { days follow-up }
$$

- The specimens from all groups did not show inflammatory pulp reactions.

- $\quad$ All three materials induced the formation of a complete mineralized tissue, with the highest thickness in the case of TCS 50.

- $\quad$ In the MTA group, the matrix had a tubular structure with calcifications entrapped in the matrix.

- In some samples from the TheraCal LC group, necrotic pulp tissue and a blood clot were present underneath the exposure site, but the deeper area of the reparative dentin presented continuous tubes.
Biodentine

Experimental group

(Septodont,

Tziafa, et al., 2014 [101] Saint-Maur-des-Fossés, France)

MTA

Control group

(Angelus, Londrina, PR, Brazil)

\section{3 weeks follow-up}

- None of the two biomaterials showed a mature bridge formation.

8 weeks follow-up

Miniature Incisors, canines, - Reactionary dentin formation around the exposure site associated with the newly swine pigs premolars, molars $\quad$ formed matrix.

- $\quad$ Both test groups presented a mineralized matrix formation in the form of a complete hard tissue bridge, with no detectable inflammatory responses or pulp necrosis.

\section{3 weeks follow-up}

- $\quad$ All beta-TCP specimens presented new dentin bridge formation with a normal histological pulp pattern and odontoblastic layer.

- $\quad$ All WMTA samples displayed complete thin calcified bridges with normal pulp (beta-TCP)

(RTR, Septodont)

White MTA

Shayegan, et al.,

(Dentsply, DeTrey GmbH)

White PC

Incisors,

2009 [102]

(Cantillana, Belgium)

$$
\mathrm{CH}
$$

(Dentsply, DeTrey GmbH) tissue and lack of inflammatory response.

- $\quad$ All specimens of the white- $P C$ groups showed normal pulp architecture and complete calcified bridge formation.

- In the CH group, one sample had moderate incomplete new dentin bridge formation, while the others presented complete calcified new dentin bridge formation.

- There were no significant differences between the four groups in terms of inflammatory response and hard tissue deposition. 
Table 5. Histological evaluation following DPC with calcium-silicate-based materials on primate animal model.

\begin{tabular}{|c|c|c|c|c|}
\hline Publication. & DPC Agent & Animal Type & Teeth Type & Histological Evaluation \\
\hline Cannon, et al., 2014 [93] & $\begin{array}{c}\text { TheraCal LC } \\
\text { (Bisco, Schaumburg, IL, USA) } \\
\text { Pure PC with } 2 \% \\
\text { Chlorhexidine solution, } \\
\text { Glass ionomer cement } \\
\text { (Triage, Fuji VII, GC, USA) } \\
\text { CH } \\
\text { (Dycal, Dentsply) }\end{array}$ & $\begin{array}{c}\text { Primate } \\
\text { (Capucin } \\
\text { Cebus Opella) }\end{array}$ & $\begin{array}{c}3 \text { teeth in each } \\
\text { quadrant }\end{array}$ & $\begin{array}{l}4 \text { weeks follow-up } \\
\text { - } \quad \text { Only one sample in the TheraCal } L C \text { group lacked the deposition of hard tissue, } \\
\text { most likely due to pulp necrosis. } \\
\text { - } \quad \text { A mixed result regarding the inflammatory response was present in all groups. } \\
\text { - The newly formed dentin bridge had the highest average depth in the TheraCal } \\
\text { LC group, followed by the } P C \text {, glass-ionomer cement and } C H \text { groups. }\end{array}$ \\
\hline
\end{tabular}


The histological evaluation of the dental pulp and of the new dental hard tissue formation, subsequent to the action of the DPC agent, was performed by the authors by scoring the following criteria: inflammatory cell infiltrate, pulp tissue disorganization, reparative dentin formation, quality of reparative dentin, defective area or cell inclusion, the impact of dentin fragments (dentin chips) into the pulp (Figure 2). Detailed results of the eligible studies are presented in Tables 2-5, including histological evaluations, along with the type of DPC materials used, the animals and the teeth on which DPC was performed.

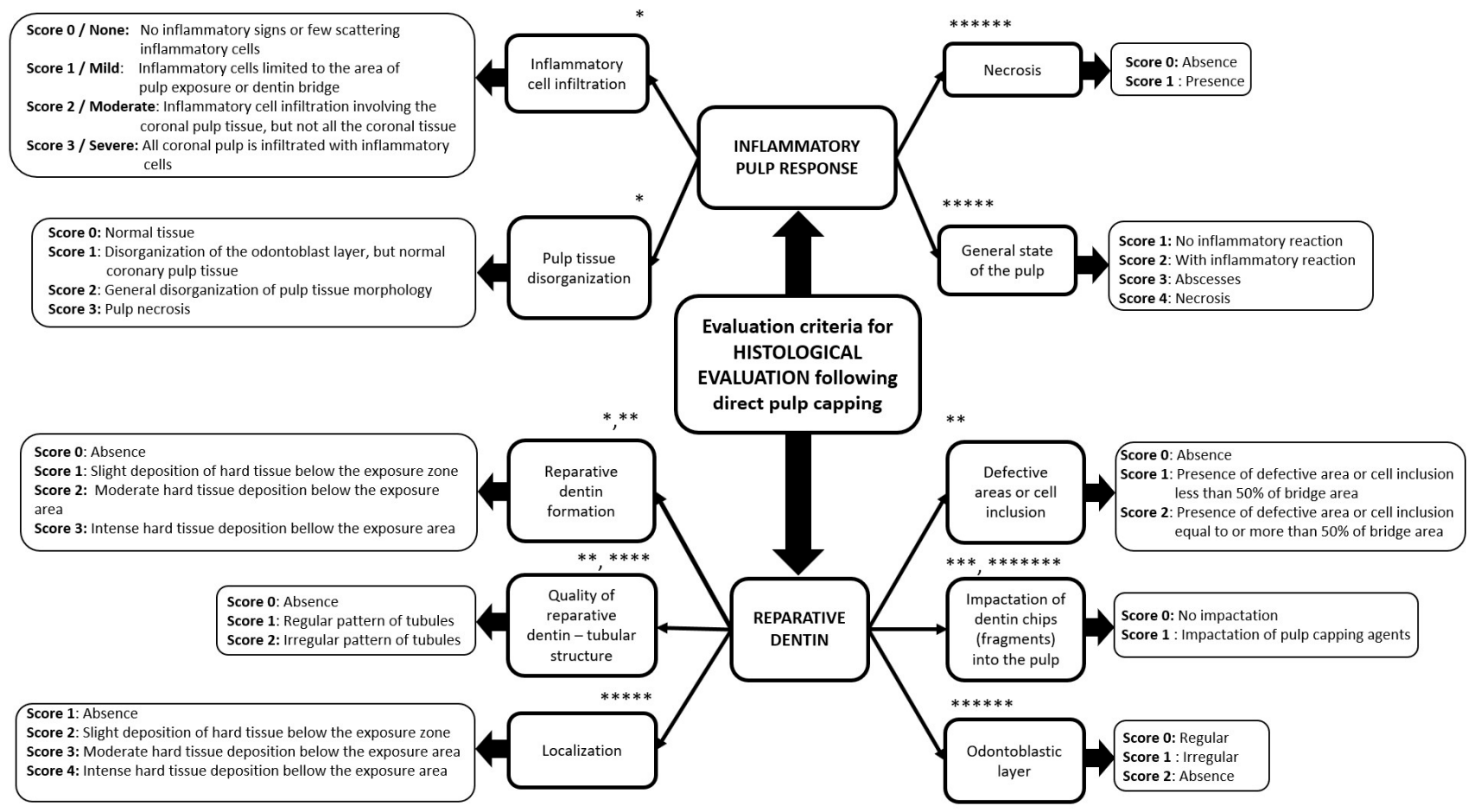

Figure 2. The histological evaluation criteria used for dental pulp characterization following inflammatory pulp response and new hard tissue formation, subsequent to the action of the DPC agent $\left({ }^{*}[103],{ }^{* *}[116],{ }^{* * *}[115],{ }^{* * * *}[112],{ }^{* * * * *}[97]\right.$, $* * * * * *[107], * * * * * * *[95])$.

\section{Discussions}

The main purpose of DPC is to maintain the full integrity of the pulpal tissue in different pathological exposure conditions. An ideal DPC material should not induce inflammatory pulpal reactions, which may lead to necrosis, and should provide a quality repair dentin at the level of the exposure site [118]. Calcium-silicate-based materials have good efficacy on dental pulp when used as DPC agents [119].

MTA's novelty was represented by the setting reaction that could occur in an aqueous environment. Following the setting reaction, calcium oxide converts into $\mathrm{CH}$ and calcium ions are released, stimulating cell adhesion and proliferation and leading to an increase of the $\mathrm{pH}$, which offers antibacterial activity [120]. MTA can induce and stimulate cells to form hard tissue deposition and promote mineralization [121]. MTA's ability to release calcium ions can induce dental pulp stem proliferation [122]. MTA showed a relatively fast pulp response by deposition of newly formed hard tissue, with slight signs of pulp inflammation [94].

$\mathrm{CH}$ was considered a gold standard pulp-tissue-regenerating material due to its biocompatibility, highly alkaline $\mathrm{pH}$, bactericidal effect and capability to induce tertiary dentin formation [123]. Furthermore, $\mathrm{CH}$ had high clinical success as DPC material, documented in studies that followed patients for more than 10 years [124]. However, due to its high alkalinity, it also induces necrosis and inflammatory pulp responses [38]. Other disadvantages are its high solubility [125] and its lack of adherence to hard tissues, failing 
to offer an optimal seal, although, by the time of its full dissolution, the dentin bridge seems to be fully formed [126]. There is also stated that the dentin bridge induced by $\mathrm{CH}$ presents "tunnel defects" [40]; however, there is data that shows that the aspect of these defects improved with the thickening of the dentin bridge [127]. Light-cured $\mathrm{CH}$ has a better success rate than conventional $\mathrm{CH}$ because it is less subject to the process of hydrolysis of $\mathrm{CH}$ in the presence of moisture [128]. MTA has a higher clinical success rate than $\mathrm{CH}$ [98] and can induce the formation of much thicker dentin bridges [105,129]. However, in a clinical study on human vital teeth, performing indirect pulp capping with MTA and $\mathrm{CH}$, similar behavior of the two materials was observed after clinical and radiological assessment, for 24 months [130].

Conventionally, it was believed that $\mathrm{CH}$ irritates the pulp due to its alkaline $\mathrm{pH}$ and stimulated tertiary dentin deposition [131]. CH and MTA have similar mechanisms of action based on calcium oxide, which reacts to carbon dioxide in tissues. Calcite granulations are formed, and fibronectin accumulates to the site, favoring cellular migration, proliferation, adhesion and differentiation [132], which leads to hard tissue formation [133,134]. During this process, bioactive molecules are released, Bone Morphogenic Protein (BMP) and Transforming Growth Factor-Beta One (TBF- $\beta 1$ ), which mediate pulp regeneration and are incorporated in the dentin matrix during dentinogenesis [131,135-137].

The studies we have included in this review showed that animals pulp capped with MTA showed more frequently complete formation of new dentin bridges, with tubular structures, superior morphology and a lower rate of pulpal inflammation and necrosis, when compared to $\mathrm{CH}[96,99,102,104,105,117]$. Even though MTA is more expensive than $\mathrm{CH}$ [3], it may be more cost-effective due to its stable clinical results over time, compared to $\mathrm{CH}$, which requires future costly reinterventions [138].

Some authors tested modified MTA cements by incorporating different additives in order to improve their physical and biological performances; however, the results we have collected do not entirely support this supposition, especially concerning histological results. The addition of calcium chloride or amorphous calcium lactate gluconate-based liquid accelerated the setting reaction and improved handling, while the addition of propylene glycol provided a higher $\mathrm{pH}$, with antibacterial effect [139], better flowability and increased calcium release [140]. There were no significant differences concerning acute inflammation between MTA with or without calcium chloride as DPC agents; however, MTA with calcium chloride showed a higher chronic inflammatory response, and the quality of the dentin bridge was inferior [92]. MTA modified with melatonin, a highly lipophilic hormone, which acts as a circadian rhythm regulator and anti-inflammatory agent [141], showed no significant differences regarding hard tissue deposition and pulp inflammatory response when compared to conventional MTA [107].

PC, with a similar composition as MTA [142,143], can be modified to achieve better performance through the addition of $20 \%$ bismuth oxide for radiopacity [106], the addition of antibacterial agents such as $2 \%$ chlorhexidine solution [93], calcium chloride to accelerate the setting reaction by increasing the hydration reaction and methylcellulose to avoid early washout following its application to the dentin [144]. PC cement is biocompatible and favors cellular attachment and growth [145]. PC can be considered as a low-cost substitute to MTA [146]. When PC with 20\% bismuth oxide addition was compared to MTA and Port Cal (a material obtained from PC with $20 \%$ bismuth oxide and $10 \% \mathrm{CH}$ powder added in the mixture), MTA had the best histological outcome followed by Port Cal, while PC had the highest inflammatory cell count. Although similar in composition, MTA's fine and homogeneous particles' content, as opposed to PC, offer this material its better neodentinogenetic characteristics [147], while the addition of $\mathrm{CH}$ in Port Cal may be the reason for less hard dentinal tissue deposition, due to its weaker and porous composition [106,147].

TheraCal LC, a hybrid DPC agent, induced dentinal hard tissue deposition at the level of exposure site with low inflammatory cell response [93,100]. This is due to the formation of $\mathrm{CH}$ following the hydration reaction, which created the premise of a high 
$\mathrm{pH}$ with antibacterial activity and the formation of calcium ions that induced morphodifferentiation and proliferation of odontoblast-like cells at the level of pulp exposure site [148]. Even though TheraCal LC contains resin in its composition, and there is a risk of remaining unpolymerized resin monomers, it has good biocompatibility compared to $\mathrm{CH}$ [149]. However, one study indicated that after $72 \mathrm{~h}$, TheraCal LC showed a decrease in the percentage of cell viability, similar to $\mathrm{CH}$ [150]. Another study reported a lack of dentin bridge formation, probably due to pulp necrosis [93], and also the presence of necrotic pulp tissue and blood cloth underneath the exposure site at 70 days follow-up [100].

Biodentine and MTA had a similar effect concerning new dentin bridge formation capacity and induced fewer inflammatory signs when applied on human dental pulps following iatrogenic pulp exposure [151]. These aspects may be due to the fact that Biodentine induces odontoblastic differentiation from human dental pulp stem cells [152] and shows better biocompatibility and bioactivity than MTA and TheraCal LC [153]. The results related to Biodentine revealed that this material could induce thicker dentinal bridges than MTA and nHap, a nano-hydroxyapatite material [98], and a lower inflammatory pulp response [101].

iRoot BP Plus showed a slightly more favorable result as all specimens generated new dentinal tissue when compared to MTA [154]. In terms of bio-efficiency, both iRoot BP Plus and MTA had a similar effect on the dental pulps, leading to the deposition of a dentin structure with regular or irregular dentinal tubes pattern [155]. This aspect is mainly due to the ability of iRoot BP Plus to form apatite structures [82].

Bioactive glass materials [117] induced the formation of new dentin bridge formation one month after application, with low signs of pulpal inflammation and hard tissue deposition [112]. New endodontic cement (NEC) that contains several calcium compounds showed better results than MTA but without major differences. NEC specimens had a better organized odontoblastic layer with thick dentin bridges and a lack of pulp inflammation signs [96]. Nano-hydroxyapatite-based materials [98], Endocem, a fast-setting calciumsilicate-based cement containing zirconium oxide [108,110], ß-tricalcium phosphate [78], $\alpha$ tricalcium phosphate-based materials [109] or Bio-MA [115,116] showed similar favorable pulp responses when compared to MTA.

Different materials such as dentin adhesives [99], light-cured resins [114], light-cured glass-ionomer cement [109], odontoblastic differentiating material [113] or biomimetic carbonated apatite [97] have been tested in an attempt to come up with new pulp-capping agents. In most cases, when compared to MTA, these materials showed less favorable results in terms of pulp inflammatory response and hard tissue deposition. New dentin bridge formation occurred in every specimen of the MTA group, while in the group with polymeric-based materials, there was no hard tissue deposition, even if the pulp tissue lacked any signs of inflammation [114] or, as shown in other studies, adhesive materials only induced formation in a few samples, and in several, there was inflammation and pulp necrosis [112]. Light-cured resin-based materials, such as restorative materials and dentin bonding agents, can induce pulpal adverse reactions due to the remaining incompletely polymerized monomer that may diffuse into the dental pulp and induce cell death [156] and to the shrinkage following the polymerization reaction that favors micro-infiltration [145]. Controversially, DPC with dentin adhesives on children's permanent teeth showed a beneficial effect without signs of pulpal inflammation or necrosis and with a low failure rate [157], and in teeth pulp capped with a glutaraldehyde-based dentin-adhesive system, the results were favorable over a period of 6 months [158].

Summarizing, our results show that immediately after DPC, there is a substantial acute inflammatory response [103] underneath the pulp exposure, that tends to intensify over the next period of time and starts to diminish gradually afterwards [102,112], so as to become absent after one month following the intervention $[96,97,100,101,110]$. The lowest inflammation response was present in MTA samples and bioceramic materials, while $\mathrm{CH}$ samples showed a moderate response, and resin-based materials showed more persistent responses. The inflammatory process is beneficial and necessary for pulp healing and 
dental bridge deposition, as long as it is limited and does not lead to extensive necrosis and cell apoptosis [159]. Partial necrosis beneath the capping site was observed since the 1st day of follow-up [94], and the area extended in the next period [98]. Superficial necrosis was associated with the destruction of the odontoblastic cell layer [106] at 3 weeks after the intervention. At approximately 3 to 4 weeks, the odontoblast-like cells were present and organized in a palisade pattern underneath the injury site $[110,116]$. Additionally, disorganization of cell morphology adjacent to exposure site was observed at 3 weeks follow-up [103], but they became better organized within the following month [96]. Lack of necrosis was reported from the 30th day [101,107] and was associated with a continuous odontoblastic layer at 3 months follow-up [106]. Irrespective of the pulp-capping agent, during the first days following DPC, there were no signs of mineralized tissue at the exposure site. Only after 7 days, a newly formed mineralized matrix was observed, especially in MTA and Biodentine samples $[103,112,115]$. A dentinal tubular structure showed up during the 2nd week of follow-up [94], and by the 4th week, a heavier hard tissue deposition was observed, with both regular and irregular tubular patterns $[93,100,112,114]$, that connected to the primary dentin [111]. Complete hard tissue bridge was reported in few studies, only in those that had longer follow-up periods [95,102]. The use of most resin-based materials, glass-ionomers and BCAp was not associated with signs of dental bridge formation [97,108-110], while $\mathrm{CH}$ had fewer spectacular results, as compared to MTA or bioceramic materials [104-106].

A possible limitation of our study is that we performed the search only in PubMed (Medline) database, and we excluded articles published in other languages than English. The results were heterogeneous, and a methodological inconsistency was observed throughout the included publications, concerning the animal model used, the pulp-capping agents, the follow-up periods and the outcomes assessed. Additionally, the evaluation criteria also made it difficult to perform a more concise analysis of the extracted data.

\section{Conclusions}

From in vivo experiments on animal models, it can be clearly seen that MTA remains the most commonly used and optimum DPC agent for vital pulp therapy, either as a material in the test group or as a reference material. MTA has taken over the gold standard from $\mathrm{CH}$ cements, remaining today a reference standard in this group of pulp-capping materials due to its properties in terms of biocompatibility, stimulation of odontoblasts, differentiation and proliferation of dental pulp cells in order to produce tertiary dentin, as shown on molecular and histological levels. As far as histological findings revealed, resin-based materials seem to be less suitable materials for pulp capping. More recently developed materials, such as bioceramic materials derived from MTA, show similar results and even surpass the ones already grounded for MTA. However, due to the diversity of animal models/teeth, type of pulp exposure, and DPC conditions, the translational success rate for some of the calcium-silicate cements might cover a wide range in human permanent/temporary teeth.

Author Contributions: Conceptualization, M.A., A.C.D. and I.D. Methodology, M.A., R.I., R.P.V. and A.C.D. Resources, R.I., R.P.V. and M.A. Investigation, M.A., A.C. and A.C.D. Writing-original draft preparation, R.P.V. and M.A. Writing-review and editing, M.A., A.C., R.P.V. and A.C.D. Supervision, A.C.D. and A.C. Funding acquisition, A.C.D. All authors have read and agreed to the published version of the manuscript.

Funding: This work was supported by a grant of Ministry of Research and Innovation, CNCSUEFISCDI, project number PN-III-P4-ID-PCE-2016-0506, within PNCDI III.

Conflicts of Interest: The authors declare no conflict of interest. 


\section{References}

1. Murray, P.E.; About, I.; Lumley, P.J.; Smith, G.A.Y.; Franquin, J.C.; Smith, A.J. Postoperative pulpal and repair responses. J. Am. Dent. Assoc. 2000, 131, 321-329. [CrossRef] [PubMed]

2. Murray, P.E.; Windsor, L.J.; Smyth, T.W.; Hafez, A.A.; Cox, C.F. Analysis of pulpal reactions to restorative procedures, materials, pulp capping, and future therapies. Crit. Rev. Oral. Biol. Med. 2002, 13, 509-520. [CrossRef] [PubMed]

3. Didilescu, A.C.; Cristache, C.M.; Andrei, M.; Voicu, G.; Perlea, P. The effect of dental pulp-capping materials on hard-tissue barrier formation: A systematic review and meta-analysis. J. Am. Dent. Assoc. 2018, 149, 903-917.e904. [CrossRef]

4. Cohenca, N.; Paranjpe, A.; Berg, J. Vital pulp therapy. Dent. Clin. N. Am. 2013, 57, 59-73. [CrossRef] [PubMed]

5. Parolia, A.; Kundabala, M.; Rao, N.N.; Acharya, S.R.; Agrawal, P.; Mohan, M.; Thomas, M. A comparative histological analysis of human pulp following direct pulp capping with Propolis, mineral trioxide aggregate and Dycal. Aust. Dent. J. 2010, 55, 59-64. [CrossRef] [PubMed]

6. Aeinehchi, M.; Eslami, B.; Ghanbariha, M.; Saffar, A.S. Mineral trioxide aggregate (MTA) and calcium hydroxide as pulp-capping agents in human teeth: A preliminary report. Int. Endod. J. 2003, 36, 225-231. [CrossRef]

7. Cho, S.Y.; Seo, D.G.; Lee, S.J.; Lee, J.; Lee, S.J.; Jung, I.Y. Prognostic factors for clinical outcomes according to time after direct pulp capping. J. Endod. 2013, 39, 327-331. [CrossRef] [PubMed]

8. Kumar, G.S. Orban's Oral Histology and Embryology; Elsevier: Taramani, India, 2011.

9. Fehrenbach, M.J.; Popowics, T. Illustrated Dental Embryology, Histology, and Anatomy; Saunders Elsevier: Philadelphia, PA, USA, 2015.

10. Gronthos, S.; Brahim, J.; Li, W.; Fisher, L.W.; Cherman, N.; Boyde, A.; DenBesten, P.; Robey, P.G.; Shi, S. Stem cell properties of human dental pulp stem cells. J. Dent. Res. 2002, 81, 531-535. [CrossRef]

11. Holland, G.R. Morphological features of dentine and pulp related to dentine sensitivity. Arch. Oral. Biol. 1994, 39, 3s-11s. [CrossRef]

12. Yu, C.; Abbott, P.V. An overview of the dental pulp: Its functions and responses to injury. Aust. Dent. J. 2007, 52, S4-S16. [CrossRef]

13. Smith, A.J.; Smith, J.G.; Shelton, R.M.; Cooper, P.R. Harnessing the Natural Regenerative Potential of the Dental Pulp. Dent. Clin. N. Am. 2012, 56, 589-601. [CrossRef] [PubMed]

14. Tziafas, D.; Smith, A.J.; Lesot, H. Designing new treatment strategies in vital pulp therapy. J. Dent. 2000, 28, 77-92. [CrossRef]

15. Smith, A.J.; Cassidy, N.; Perry, H.; Bègue-Kirn, C.; Ruch, J.V.; Lesot, H. Reactionary dentinogenesis. Int. J. Dev. Biol. 1995, 39, 273-280.

16. Mitsiadis, T.A.; Fried, K.; Goridis, C. Reactivation of Delta-Notch Signaling after Injury: Complementary Expression Patterns of Ligand and Receptor in Dental Pulp. Exp. Cell Res. 1999, 246, 312-318. [CrossRef] [PubMed]

17. Mitsiadis, T.A.; Rahiotis, C. Parallels between tooth development and repair: Conserved molecular mechanisms following carious and dental injury. J. Dent. Res. 2004, 83, 896-902. [CrossRef] [PubMed]

18. da Rosa, W.L.O.; Piva, E.; da Silva, A.F. Disclosing the physiology of pulp tissue for vital pulp therapy. Int. Endod. J. 2018, 51, 829-846. [CrossRef] [PubMed]

19. Simon, S.; Smith, A.J.; Berdal, A.; Lumley, P.J.; Cooper, P.R. The MAP Kinase Pathway Is Involved in Odontoblast Stimulation via p38 Phosphorylation. J. Endod. 2010, 36, 256-259. [CrossRef]

20. Brizuela, C.; Ormeno, A.; Cabrera, C.; Cabezas, R.; Silva, C.I.; Ramirez, V.; Mercade, M. Direct Pulp Capping with Calcium Hydroxide, Mineral Trioxide Aggregate, and Biodentine in Permanent Young Teeth with Caries: A Randomized Clinical Trial. J. Endod. 2017, 43, 1776-1780. [CrossRef]

21. Jalan, A.; Warhadpande, M.; Dakshindas, D. A comparison of human dental pulp response to calcium hydroxide and Biodentine as direct pulp-capping agents. J. Conserv. Dent. 2017, 20, 129-133. [CrossRef]

22. Yildirim, S.; Can, A.; Arican, M.; Embree, M.C.; Mao, J.J. Characterization of dental pulp defect and repair in a canine model. Am. J. Dent. 2011, 24, 331-335. [PubMed]

23. do Nascimento, A.B.; Fontana, U.F.; Teixeira, H.M.; Costa, C.A. Biocompatibility of a resin-modified glass-ionomer cement applied as pulp capping in human teeth. Am. J. Dent. 2000, 13, 28-34. [PubMed]

24. Dammaschke, T.; Wolff, P.; Sagheri, D.; Stratmann, U.; Schäfer, E. Mineral trioxide aggregate for direct pulp capping: A histologic comparison with calcium hydroxide in rat molars. Quintessence Int. 2010, 41, e20-e30. [PubMed]

25. Ford, T.R.P.; Torabinejad, M.; Abedi, H.R.; Bakland, L.K.; Kariyawasam, S.P. Using mineral trioxide aggregate as a pulp-capping material. J. Am. Dent. Assoc. 1996, 127, 1491-1494. [CrossRef] [PubMed]

26. da Silva, L.A.; de Freitas, A.C.; de Carvalho, F.K.; de Queiroz, A.M.; Nelson-Filho, P.; Porto-Neto, S.T. Direct pulp capping with a self-etching adhesive system: Histopathologic evaluation in dogs' teeth. Oral. Surg. Oral. Med. Oral. Pathol. Oral. Radiol. Endod. 2009, 108, e34-e40. [CrossRef] [PubMed]

27. Ishizaki, N.T.; Matsumoto, K.; Kimura, Y.; Wang, X.; Yamashita, A. Histopathological study of dental pulp tissue capped with enamel matrix derivative. J. Endod. 2003, 29, 176-179. [CrossRef] [PubMed]

28. Dick, H.M.; Carmichael, D.J. Reconstituted antigen-poor collagen preparations as potential pulp-capping agents. J. Endod. 1980, 6, 641-644. [CrossRef]

29. Aminabadi, N.A.; Farahani, R.M.; Oskouei, S.G. Formocresol versus calcium hydroxide direct pulp capping of human primary molars: Two year follow-up. J. Clin. Pediatr Dent. 2010, 34, 317-321. [CrossRef] [PubMed] 
30. Sübay, R.K.; Aşci, S. Human pulpal response to hydroxyapatite and a calcium hydroxide material as direct capping agents. Oral Surg. Oral. Med. Oral. Pathol. 1993, 76, 485-492. [CrossRef]

31. Estrela, C.; Bammann, L.L.; Estrela, C.R.; Silva, R.S.; Pécora, J.D. Antimicrobial and chemical study of MTA, Portland cement, calcium hydroxide paste, Sealapex and Dycal. Braz. Dent. J. 2000, 11, 3-9.

32. Guerreiro-Tanomaru, J.M.; Cornélio, A.L.G.; Andolfatto, C.; Salles, L.P.; Tanomaru-Filho, M. pH and Antimicrobial Activity of Portland Cement Associated with Different Radiopacifying Agents. ISRN Dentistry 2012, 2012, 469019. [CrossRef]

33. Lewis, B. The obsolescence of formocresol. Br. Dent. J. 2009, 207, 525-528. [CrossRef] [PubMed]

34. Tewari, S.; Tewari, S. Assessment of coronal microleakage in intermediately restored endodontic access cavities. Oral. Surg. Oral. Med. Oral. Pathol. Oral. Radiol. Endod. 2002, 93, 716-719. [CrossRef] [PubMed]

35. Torabinejad, M.; Hong, C.U.; Pitt Ford, T.R.; Kettering, J.D. Cytotoxicity of four root end filling materials. J. Endod. 1995, 21, 489-492. [CrossRef]

36. Hume, W.R. An analysis of the release and the diffusion through dentin of eugenol from zinc oxide-eugenol mixtures. J. Dent. Res. 1984, 63, 881-884. [CrossRef] [PubMed]

37. Glass, R.L.; Zander, H.A. Pulp healing. J. Dent. Res. 1949, 28, 97-107. [CrossRef]

38. Hilton, T.J. Keys to clinical success with pulp capping: A review of the literature. Oper. Dent. 2009, 34, 615-625. [CrossRef] [PubMed]

39. Andelin, W.E.; Shabahang, S.; Wright, K.; Torabinejad, M. Identification of hard tissue after experimental pulp capping using dentin sialoprotein (DSP) as a marker. J. Endod. 2003, 29, 646-650. [CrossRef] [PubMed]

40. Cox, C.F.; Sübay, R.K.; Ostro, E.; Suzuki, S.; Suzuki, S.H. Tunnel defects in dentin bridges: Their formation following direct pulp capping. Oper. Dent. 1996, 21, 4-11.

41. Koike, T.; Polan, M.; Izumikawa, M.; Saito, T. Induction of Reparative Dentin Formation on Exposed Dental Pulp by Dentin Phosphophoryn/Collagen Composite. BioMed Res. Int. 2014, 2014, 745139. [CrossRef] [PubMed]

42. Paranjpe, A.; Zhang, H.; Johnson, J.D. Effects of mineral trioxide aggregate on human dental pulp cells after pulp-capping procedures. J. Endod. 2010, 36, 1042-1047. [CrossRef] [PubMed]

43. Zhou, S.; Ma, J.; Shen, Y.; Haapasalo, M.; Ruse, N.D.; Yang, Q.; Troczynski, T. In vitro studies of calcium phosphate silicate bone cements. J. Mater. Sci. Mater. Med. 2013, 24, 355-364. [CrossRef] [PubMed]

44. Steffen, R.; van Waes, H. Understanding mineral trioxide aggregate/Portland-cement: A review of literature and background factors. Eur. Arch. Paediatry Dent. 2009, 10, 93-97. [CrossRef] [PubMed]

45. Negm, A.; Hassanien, E.; Abu-Seida, A.; Nagy, M. Physical evaluation of a new pulp capping material developed from portland cement. J. Clin. Exp. Dent. 2016, 8, e278-e283. [CrossRef] [PubMed]

46. França, T.; Silva, R.; Queiroz, M.; Aguiar, C. Arsenic content in Portland cement: A literature review. Indian J. Dent. Res. 2010, 21, 591-595. [CrossRef] [PubMed]

47. Duarte, M.A.; De Oliveira Demarchi, A.C.; Yamashita, J.C.; Kuga, M.C.; De Campos Fraga, S. Arsenic release provided by MTA and Portland cement. Oral. Surg. Oral. Med. Oral. Pathol. Oral. Radiol. Endod. 2005, 99, 648-650. [CrossRef] [PubMed]

48. Monteiro Bramante, C.; Demarchi, A.C.; de Moraes, I.G.; Bernadineli, N.; Garcia, R.B.; Spångberg, L.S.; Duarte, M.A. Presence of arsenic in different types of MTA and white and gray Portland cement. Oral. Surg. Oral. Med. Oral. Pathol. Oral. Radiol. Endod. 2008, 106, 909-913. [CrossRef] [PubMed]

49. De-Deus, G.; Coutinho-Filho, T. The use of white Portland cement as an apical plug in a tooth with a necrotic pulp and wide-open apex: A case report. Int. Endod. J. 2007, 40, 653-660. [CrossRef]

50. Camilleri, J.; Montesin, F.E.; Brady, K.; Sweeney, R.; Curtis, R.V.; Ford, T.R. The constitution of mineral trioxide aggregate. Dent. Mater. 2005, 21, 297-303. [CrossRef]

51. Sipert, C.R.; Hussne, R.P.; Nishiyama, C.K.; Torres, S.A. In vitro antimicrobial activity of Fill Canal, Sealapex, Mineral Trioxide Aggregate, Portland cement and EndoRez. Int. Endod. J. 2005, 38, 539-543. [CrossRef] [PubMed]

52. Marques, N.; Lourenço Neto, N.; Fernandes, A.P.; Rodini, C.; Hungaro Duarte, M.; Rios, D.; Machado, M.A.; Oliveira, T. Pulp tissue response to Portland cement associated with different radio pacifying agents on pulpotomy of human primary molars. $J$. Microsc. 2015, 260, 281-286. [CrossRef] [PubMed]

53. Bortoluzzi, E.A.; Broon, N.J.; Bramante, C.M.; Felippe, W.T.; Tanomaru Filho, M.; Esberard, R.M. The influence of calcium chloride on the setting time, solubility, disintegration, and $\mathrm{pH}$ of mineral trioxide aggregate and white Portland cement with a radiopacifier. J. Endod. 2009, 35, 550-554. [CrossRef] [PubMed]

54. De-Deus, G.; Petruccelli, V.; Gurgel-Filho, E.; Coutinho-Filho, T. MTA versus Portland cement as repair material for furcal perforations: A laboratory study using a polymicrobial leakage model. Int. Endod. J. 2006, 39, 293-298. [CrossRef] [PubMed]

55. Nagy, M.M.; Tawfik, H.E.; Hashem, A.A.; Abu-Seida, A.M. Regenerative potential of immature permanent teeth with necrotic pulps after different regenerative protocols. J. Endod. 2014, 40, 192-198. [CrossRef] [PubMed]

56. Torabinejad, M.; Chivian, N. Clinical applications of mineral trioxide aggregate. J. Endod. 1999, 25, 197-205. [CrossRef]

57. Patel, N.; Patel, K.; Baba, S.M.; Jaiswal, S.; Venkataraghavan, K.; Jani, M. Comparing Gray and White Mineral Trioxide Aggregate as a Repair Material for Furcation Perforation: An in Vitro Dye Extraction Study. J. Clin. Diagn. Res. 2014, 8, ZC70-ZC73. [CrossRef] [PubMed]

58. Chng, H.K.; Islam, I.; Yap, A.U.; Tong, Y.W.; Koh, E.T. Properties of a new root-end filling material. J. Endod. 2005, 31, 665-668. [CrossRef] 
59. Gandolfi, M.G.; Siboni, F.; Prati, C. Chemical-physical properties of TheraCal, a novel light-curable MTA-like material for pulp capping. Int. Endod. J. 2012, 45, 571-579. [CrossRef] [PubMed]

60. Voicu, G.; Didilescu, A.C.; Stoian, A.B.; Dumitriu, C.; Greabu, M.; Andrei, M. Mineralogical and Microstructural Characteristics of Two Dental Pulp Capping Materials. Materials 2019, 12, 1772. [CrossRef]

61. Arandi, N.Z.; Rabi, T. TheraCal LC: From Biochemical and Bioactive Properties to Clinical Applications. Int. J. Dent. 2018, 2018, 3484653. [CrossRef] [PubMed]

62. Poggio, C.; Beltrami, R.; Colombo, M.; Ceci, M.; Dagna, A.; Chiesa, M. In vitro antibacterial activity of different pulp capping materials. J. Clin. Exp. Dent. 2015, 7, e584-e588. [CrossRef] [PubMed]

63. Hebling, J.; Lessa, F.C.; Nogueira, I.; Carvalho, R.M.; Costa, C.A. Cytotoxicity of resin-based light-cured liners. Am. J. Dent. 2009, 22, 137-142. [PubMed]

64. Bakhtiar, H.; Nekoofar, M.H.; Aminishakib, P.; Abedi, F.; Naghi Moosavi, F.; Esnaashari, E.; Azizi, A.; Esmailian, S.; Ellini, M.R.; Mesgarzadeh, V.; et al. Human Pulp Responses to Partial Pulpotomy Treatment with TheraCal as Compared with Biodentine and ProRoot MTA: A Clinical Trial. J. Endod. 2017, 43, 1786-1791. [CrossRef]

65. Jeanneau, C.; Laurent, P.; Rombouts, C.; Giraud, T.; About, I. Light-cured Tricalcium Silicate Toxicity to the Dental Pulp. J. Endod. 2017, 43, 2074-2080. [CrossRef] [PubMed]

66. Priyadarsini, S.; Mukherjee, S.; Mishra, M. Nanoparticles used in dentistry: A review. J. Oral. Biol. Craniofac. Res. 2018, 8, 58-67. [CrossRef] [PubMed]

67. Parirokh, M.; Torabinejad, M.; Dummer, P.M.H. Mineral trioxide aggregate and other bioactive endodontic cements: An updated overview-part I: Vital pulp therapy. Int. Endod. J. 2018, 51, 177-205. [CrossRef] [PubMed]

68. Lipski, M.; Nowicka, A.; Kot, K.; Postek-Stefańska, L.; Wysoczańska-Jankowicz, I.; Borkowski, L.; Andersz, P.; Jarząbek, A.; Grocholewicz, K.; Sobolewska, E.; et al. Factors affecting the outcomes of direct pulp capping using Biodentine. Clin. Oral. Investig. 2018, 22, 2021-2029. [CrossRef]

69. About, I. Biodentine: From biochemical and bioactive properties to clinical applications. G. Ital. Endod. 2016, 30, 81-88. [CrossRef]

70. Malkondu, Ö.; Kazandağ, M.K.; Kazazoğlu, E. A Review on Biodentine, a Contemporary Dentine Replacement and Repair Material. BioMed Res. Int. 2014, 2014, 160951. [CrossRef]

71. Loison-Robert, L.S.; Tassin, M.; Bonte, E.; Berbar, T.; Isaac, J.; Berdal, A.; Simon, S.; Fournier, B.P.J. In vitro effects of two silicatebased materials, Biodentine and BioRoot RCS, on dental pulp stem cells in models of reactionary and reparative dentinogenesis. PLoS ONE 2018, 13, e0190014. [CrossRef]

72. Ree, D.M.; Schwartz, R. Clinical applications of bioceramic materials in endodontics. Endod. Pract. 2015, 7, 1-9.

73. Jefferies, S. Bioactive and biomimetic restorative materials: A comprehensive review. Part II. J. Esthet. Restor Dent. 2014, 26, 27-39. [CrossRef]

74. Nekoofar, M.H.; Stone, D.F.; Dummer, P.M. The effect of blood contamination on the compressive strength and surface microstructure of mineral trioxide aggregate. Int. Endod. J. 2010, 43, 782-791. [CrossRef] [PubMed]

75. Raghavendra, S.S.; Jadhav, G.R.; Gathani, K.M.; Kotadia, P. Bioceramics in endodontics-a review. J. Istanb. Univ. Fac. Dent. 2017, 51, S128-S137. [CrossRef]

76. Šimundić Munitić, M.; Poklepović Peričić, T.; Utrobičić, A.; Bago, I.; Puljak, L. Antimicrobial efficacy of commercially available endodontic bioceramic root canal sealers: A systematic review. PLoS ONE 2019, 14, e0223575. [CrossRef] [PubMed]

77. Demirkaya, K. Evaluation of micro surface structure and chemical composition of two different calcium silicate-containing filling materials. Turk. Endod. J. 2018. [CrossRef]

78. Zhu, L.; Yang, J.; Zhang, J.; Peng, B. A comparative study of BioAggregate and ProRoot MTA on adhesion, migration, and attachment of human dental pulp cells. J. Endod. 2014, 40, 1118-1123. [CrossRef] [PubMed]

79. Zhang, S.; Yang, X.; Fan, M. BioAggregate and iRoot BP Plus optimize the proliferation and mineralization ability of human dental pulp cells. Int. Endod. J. 2013, 46, 923-929. [CrossRef] [PubMed]

80. Jung, J.Y.; Woo, S.M.; Lee, B.N.; Koh, J.T.; Nör, J.E.; Hwang, Y.C. Effect of Biodentine and Bioaggregate on odontoblastic differentiation via mitogen-activated protein kinase pathway in human dental pulp cells. Int. Endod. J. 2015, 48, 177-184. [CrossRef] [PubMed]

81. Debelian, G.; Trope, M. The use of premixed bioceramic materials in endodontics. G. Ital. Endod. 2016, 30, 70-80. [CrossRef]

82. Mahgoub, N.; Alqadasi, B.; Aldhorae, K.; Assiry, A.; Altawili, Z.M.; Tao, H. Comparison between iRoot BP Plus (EndoSequence Root Repair Material) and Mineral Trioxide Aggregate as Pulp-capping Agents: A Systematic Review. J. Int. Soc. Prev. Community Dent. 2019, 9, 542-552. [CrossRef] [PubMed]

83. Rao, Q.; Kuang, J.; Mao, C.; Dai, J.; Hu, L.; Lei, Z.; Song, G.; Yuan, G. Comparison of iRoot BP Plus and Calcium Hydroxide as Pulpotomy Materials in Permanent Incisors with Complicated Crown Fractures: A Retrospective Study. J. Endod. 2020, 46, 352-357. [CrossRef] [PubMed]

84. Zamparini, F.; Siboni, F.; Prati, C.; Taddei, P.; Gandolfi, M.G. Properties of calcium silicate-monobasic calcium phosphate materials for endodontics containing tantalum pentoxide and zirconium oxide. Clin. Oral. Investig. 2019, 23, 445-457. [CrossRef] [PubMed]

85. Lertmalapong, P.; Jantarat, J.; Srisatjaluk, R.L.; Komoltri, C. Bacterial leakage and marginal adaptation of various bioceramics as apical plug in open apex model. J. Investig. Clin. Dent. 2019, 10, e12371. [CrossRef] [PubMed] 
86. Silva, E.J.N.L.; Carvalho, N.K.; Guberman, M.R.d.C.L.; Prado, M.; Senna, P.M.; Souza, E.M.; De-Deus, G. Push-out Bond Strength of Fast-setting Mineral Trioxide Aggregate and Pozzolan-based Cements: ENDOCEM MTA and ENDOCEM Zr. J. Endod. 2017, 43, 801-804. [CrossRef] [PubMed]

87. Choi, Y.; Park, S.-J.; Lee, S.-H.; Hwang, Y.-C.; Yu, M.-K.; Min, K.-S. Biological Effects and Washout Resistance of a Newly Developed Fast-setting Pozzolan Cement. J. Endod. 2013, 39, 467-472. [CrossRef] [PubMed]

88. Jang, J.-H.; Kang, M.; Ahn, S.; Kim, S.; Kim, W.; Kim, Y.; Kim, E. Tooth Discoloration after the Use of New Pozzolan Cement (Endocem) and Mineral Trioxide Aggregate and the Effects of Internal Bleaching. J. Endod. 2013, 39, 1598-1602. [CrossRef]

89. Kim, M.; Yang, W.; Kim, H.; Ko, H. Comparison of the biological properties of ProRoot MTA, OrthoMTA, and Endocem MTA cements. J. Endod. 2014, 40, 1649-1653. [CrossRef]

90. Han, L.; Kodama, S.; Okiji, T. Evaluation of calcium-releasing and apatite-forming abilities of fast-setting calcium silicate-based endodontic materials. Int. Endod. J. 2015, 48, 124-130. [CrossRef]

91. Ashofteh Yazdi, K.; Ghabraei, S.; Bolhari, B.; Kafili, M.; Meraji, N.; Nekoofar, M.H.; Dummer, P.M.H. Microstructure and chemical analysis of four calcium silicate-based cements in different environmental conditions. Clin. Oral. Investig. 2019, 23, 43-52. [CrossRef]

92. Parirokh, M.; Asgary, S.; Eghbal, M.J.; Kakoei, S.; Samiee, M. A comparative study of using a combination of calcium chloride and mineral trioxide aggregate as the pulp-capping agent on dogs' teeth. J. Endod. 2011, 37, 786-788. [CrossRef]

93. Cannon, M.; Gerodias, N.; Viera, A.; Percinoto, C.; Jurado, R. Primate pulpal healing after exposure and TheraCal application. J. Clin. Pediatr. Dent. 2014, 38, 333-337. [CrossRef]

94. Kuratate, M.; Yoshiba, K.; Shigetani, Y.; Yoshiba, N.; Ohshima, H.; Okiji, T. Immunohistochemical analysis of nestin, osteopontin, and proliferating cells in the reparative process of exposed dental pulp capped with mineral trioxide aggregate. J. Endod. 2008, 34, 970-974. [CrossRef] [PubMed]

95. Shi, S.; Bao, Z.F.; Liu, Y.; Zhang, D.D.; Chen, X.; Jiang, L.M.; Zhong, M. Comparison of in vivo dental pulp responses to capping with iRoot BP Plus and mineral trioxide aggregate. Int. Endod. J. 2016, 49, 154-160. [CrossRef] [PubMed]

96. Asgary, S.; Eghbal, M.J.; Parirokh, M.; Ghanavati, F.; Rahimi, H. A comparative study of histologic response to different pulp capping materials and a novel endodontic cement. Oral. Surg. Oral. Med. Oral. Pathol. Oral. Radiol. Endod. 2008, 106, 609-614. [CrossRef]

97. Danesh, F.; Vahid, A.; Jahanbani, J.; Mashhadiabbas, F.; Arman, E. Effect of white mineral trioxide aggregate compared with biomimetic carbonated apatite on dentine bridge formation and inflammatory response in a dental pulp model. Int. Endod. J. 2012, 45, 26-34. [CrossRef] [PubMed]

98. Zaen El-Din, A.M.; Hamama, H.H.; Abo El-Elaa, M.A.; Grawish, M.E.; Mahmoud, S.H.; Neelakantan, P. The effect of four materials on direct pulp capping: An animal study. Aust. Endod. J. 2020, 46, 249-256. [CrossRef]

99. Akhavan, A.; Arbabzadeh, F.; Bouzari, M.; Razavi, S.M.; Davoudi, A. Pulp Response following Direct Pulp Capping with Dentin Adhesives and Mineral Trioxide Aggregate; An Animal Study. Iran. Endod. J. 2017, 12, 226-230. [CrossRef] [PubMed]

100. Li, X.; Pedano, M.S.; Camargo, B.; Hauben, E.; De Vleeschauwer, S.; Chen, Z.; De Munck, J.; Vandamme, K.; Van Landuyt, K.; Van Meerbeek, B. Experimental tricalcium silicate cement induces reparative dentinogenesis. Dent. Mater. 2018, 34, 1410-1423. [CrossRef]

101. Tziafa, C.; Koliniotou-Koumpia, E.; Papadimitriou, S.; Tziafas, D. Dentinogenic responses after direct pulp capping of miniature swine teeth with Biodentine. J. Endod. 2014, 40, 1967-1971. [CrossRef]

102. Shayegan, A.; Petein, M.; Vanden Abbeele, A. The use of beta-tricalcium phosphate, white MTA, white Portland cement and calcium hydroxide for direct pulp capping of primary pig teeth. Dent. Traumatol. 2009, 25, 413-419. [CrossRef]

103. Paula, A.B.; Laranjo, M.; Marto, C.M.; Paulo, S.; Abrantes, A.M.; Fernandes, B.; Casalta-Lopes, J.; Marques-Ferreira, M.; Botelho, M.F.; Carrilho, E. Evaluation of dentinogenesis inducer biomaterials: An in vivo study. J. Appl. Oral. Sci. 2020, 28, e20190023. [CrossRef] [PubMed]

104. Briso, A.L.; Rahal, V.; Mestrener, S.R.; Dezan Junior, E. Biological response of pulps submitted to different capping materials. Braz. Oral. Res. 2006, 20, 219-225. [CrossRef] [PubMed]

105. Faraco, I.M., Jr.; Holland, R. Response of the pulp of dogs to capping with mineral trioxide aggregate or a calcium hydroxide cement. Dent. Traumatol. 2001, 17, 163-166. [CrossRef]

106. Negm, A.M.; Hassanien, E.E.; Abu-Seida, A.M.; Nagy, M.M. Biological evaluation of a new pulp capping material developed from Portland cement. Exp. Toxicol. Pathol. 2017, 69, 115-122. [CrossRef] [PubMed]

107. Guerrero-Gironés, J.; Alcaina-Lorente, A.; Ortiz-Ruiz, C.; Ortiz-Ruiz, E.; Pecci-Lloret, M.P.; Rodríguez-Lozano, F.J.; Martínez, C.M.; Ortiz-Ruiz, A.J. Melatonin as an Agent for Direct Pulp-Capping Treatment. Int. J. Environ. Res. Public Health 2020, $17,1043$. [CrossRef] [PubMed]

108. Kim, K.A.; Yang, Y.M.; Kwon, Y.S.; Hwang, Y.C.; Yu, M.K.; Min, K.S. Odontogenic effects of a fast-setting calcium-silicate cement containing zirconium oxide. Dent. Mater. J. 2015, 34, 432-440. [CrossRef] [PubMed]

109. Lee, J.-B.; Park, S.-J.; Kim, H.-H.; Kwon, Y.-S.; Lee, K.-W.; Min, K.-S. Physical properties and biological/odontogenic effects of an experimentally developed fast-setting $\alpha$-tricalcium phosphate-based pulp capping material. BMC Oral. Health $2014,14,87$. [CrossRef] [PubMed]

110. Park, S.J.; Heo, S.M.; Hong, S.O.; Hwang, Y.C.; Lee, K.W.; Min, K.S. Odontogenic effect of a fast-setting pozzolan-based pulp capping material. J. Endod. 2014, 40, 1124-1131. [CrossRef] [PubMed] 
111. Liu, S.; Wang, S.; Dong, Y. Evaluation of a bioceramic as a pulp capping agent in vitro and in vivo. J. Endod. 2015, 41, 652-657. [CrossRef] [PubMed]

112. Long, Y.; Liu, S.; Zhu, L.; Liang, Q.; Chen, X.; Dong, Y. Evaluation of Pulp Response to Novel Bioactive Glass Pulp Capping Materials. J. Endod. 2017, 43, 1647-1650. [CrossRef]

113. Moazzami, F.; Ghahramani, Y.; Tamaddon, A.M.; Dehghani Nazhavani, A.; Adl, A. A histological comparison of a new pulp capping material and mineral trioxide aggregate in rat molars. Iran. Endod. J. 2014, 9, 50-55. [PubMed]

114. Simon, S.; Cooper, P.; Smith, A.; Picard, B.; Ifi, C.N.; Berdal, A. Evaluation of a new laboratory model for pulp healing: Preliminary study. Int. Endod. J. 2008, 41, 781-790. [CrossRef]

115. Trongkij, P.; Sutimuntanakul, S.; Lapthanasupkul, P.; Chaimanakarn, C.; Wong, R.; Banomyong, D. Effects of the exposure site on histological pulpal responses after direct capping with 2 calcium-silicate based cements in a rat model. Restor. Dent. Endod. 2018, 43, e36. [CrossRef] [PubMed]

116. Trongkij, P.; Sutimuntanakul, S.; Lapthanasupkul, P.; Chaimanakarn, C.; Wong, R.H.; Banomyong, D. Pulpal responses after direct pulp capping with two calcium-silicate cements in a rat model. Dent. Mater. J. 2019, 38, 584-590. [CrossRef] [PubMed]

117. Hanada, K.; Morotomi, T.; Washio, A.; Yada, N.; Matsuo, K.; Teshima, H.; Yokota, K.; Kitamura, C. In vitro and in vivo effects of a novel bioactive glass-based cement used as a direct pulp capping agent. J. Biomed. Mater. Res. B Appl. Biomater. 2019, 107, 161-168. [CrossRef]

118. Mjör, I.A.; Dahl, E.; Cox, C.F. Healing of pulp exposures: An ultrastructural study. J. Oral. Pathol. Med. 1991, $20,496-501$. [CrossRef] [PubMed]

119. Călin, C.; Sajin, M.; Moldovan, V.T.; Coman, C.; Stratul, S.I.; Didilescu, A.C. Immunohistochemical expression of non-collagenous extracellular matrix molecules involved in tertiary dentinogenesis following direct pulp capping: A systematic review. Ann. Anat. Anat. Anz. 2021, 235, 151674. [CrossRef] [PubMed]

120. Duarte, M.A.; Demarchi, A.C.; Yamashita, J.C.; Kuga, M.C.; Fraga Sde, C. pH and calcium ion release of 2 root-end filling materials. Oral. Surg. Oral. Med. Oral. Pathol. Oral. Radiol. Endod. 2003, 95, 345-347. [CrossRef] [PubMed]

121. Banava, S.; Fazlyab, M.; Heshmat, H.; Mojtahedzadeh, F.; Motahhary, P. Histological Evaluation of Single and Double-visit Direct Pulp Capping with Different Materials on Sound Human Premolars: A Randomized Controlled Clinical Trial. Iran. Endod. J. 2015, 10, 82-88. [PubMed]

122. Takita, T.; Hayashi, M.; Takeichi, O.; Ogiso, B.; Suzuki, N.; Otsuka, K.; Ito, K. Effect of mineral trioxide aggregate on proliferation of cultured human dental pulp cells. Int. Endod. J. 2006, 39, 415-422. [CrossRef] [PubMed]

123. Stuart, K.G.; Miller, C.H.; Brown, C.E.; Newton, C.W. The comparative antimicrobial effect of calcium hydroxide. Oral. Surg. Oral. Med. Oral. Pathol. Oral. Radiol. Endod. 1991, 72, 101-104. [CrossRef]

124. Robertson, A.; Andreasen, F.M.; Andreasen, J.O.; Norén, J.G. Long-term prognosis of crown-fractured permanent incisors. The effect of stage of root development and associated luxation injury. Int. J. Paediatry Dent. 2000, 10, 191-199. [CrossRef] [PubMed]

125. Petrou, M.A.; Alhamoui, F.A.; Welk, A.; Altarabulsi, M.B.; Alkilzy, M.; Splieth, C.H. A randomized clinical trial on the use of medical Portland cement, MTA and calcium hydroxide in indirect pulp treatment. Clin. Oral. Investig. 2014, 18, 1383-1389. [CrossRef] [PubMed]

126. Li, Z.; Cao, L.; Fan, M.; Xu, Q. Direct Pulp Capping with Calcium Hydroxide or Mineral Trioxide Aggregate: A Meta-analysis. J. Endod. 2015, 41, 1412-1417. [CrossRef] [PubMed]

127. Ulmansky, M.; Sela, J.; Sela, M. Scanning electron microscopy of calcium hydroxide induced bridges. J. Oral. Pathol. 1972, 1, 244-248. [CrossRef] [PubMed]

128. Straffon, L.H.; Corpron, R.L.; Bruner, F.W.; Daprai, F. Twenty-four-month clinical trial of visible-light-activated cavity liner in young permanent teeth. ASDC J. Dent. Child. 1991, 58, 124-128. [PubMed]

129. Tran, X.V.; Gorin, C.; Willig, C.; Baroukh, B.; Pellat, B.; Decup, F.; Opsahl Vital, S.; Chaussain, C.; Boukpessi, T. Effect of a calcium-silicate-based restorative cement on pulp repair. J. Dent. Res. 2012, 91, 1166-1171. [CrossRef]

130. Koc Vural, U.; Kiremitci, A.; Gokalp, S. Randomized Clinical Trial to Evaluate MTA Indirect Pulp Capping in Deep Caries Lesions After 24-Months. Oper. Dent. 2017, 42, 470-477. [CrossRef]

131. Graham, L.; Cooper, P.R.; Cassidy, N.; Nor, J.E.; Sloan, A.J.; Smith, A.J. The effect of calcium hydroxide on solubilisation of bio-active dentine matrix components. Biomaterials 2006, 27, 2865-2873. [CrossRef]

132. Nakashima, M. Bone morphogenetic proteins in dentin regeneration for potential use in endodontic therapy. Cytokine Growth Factor Rev. 2005, 16, 369-376. [CrossRef]

133. Holland, R.; de Souza, V.; Nery, M.J.; Faraco Júnior, I.M.; Bernabé, P.F.; Otoboni Filho, J.A.; Dezan Júnior, E. Reaction of rat connective tissue to implanted dentin tube filled with mineral trioxide aggregate, Portland cement or calcium hydroxide. Braz. Dent. J. 2001, 12, 3-8. [PubMed]

134. Holland, R.; de Souza, V.; Nery, M.J.; Otoboni Filho, J.A.; Bernabé, P.F.; Dezan Júnior, E. Reaction of rat connective tissue to implanted dentin tubes filled with mineral trioxide aggregate or calcium hydroxide. J. Endod. 1999, 25, 161-166. [CrossRef]

135. Duque, C.; Hebling, J.; Smith, A.J.; Giro, E.M.; Oliveira, M.F.; de Souza Costa, C.A. Reactionary dentinogenesis after applying restorative materials and bioactive dentin matrix molecules as liners in deep cavities prepared in nonhuman primate teeth. J. Oral. Rehabil. 2006, 33, 452-461. [CrossRef] [PubMed]

136. Smith, A.J. Vitality of the dentin-pulp complex in health and disease: Growth factors as key mediators. J. Dent. Educ. 2003, 67, 678-689. [CrossRef] [PubMed] 
137. Zhang, W.; Walboomers, X.F.; Jansen, J.A. The formation of tertiary dentin after pulp capping with a calcium phosphate cement, loaded with PLGA microparticles containing TGF-beta1. J. Biomed. Mater. Res. A 2008, 85, 439-444. [CrossRef]

138. Schwendicke, F.; Brouwer, F.; Stolpe, M. Calcium Hydroxide versus Mineral Trioxide Aggregate for Direct Pulp Capping: A Cost-effectiveness Analysis. J. Endod. 2015, 41, 1969-1974. [CrossRef] [PubMed]

139. Farrugia, C.; Baca, P.; Camilleri, J.; Arias Moliz, M.T. Antimicrobial activity of ProRoot MTA in contact with blood. Sci. Rep. 2017, 7, 41359. [CrossRef]

140. Lee, B.-N.; Chun, S.-J.; Chang, H.-S.; Hwang, Y.-C.; Hwang, I.-N.; Oh, W.-M. Physical properties and biological effects of mineral trioxide aggregate mixed with methylcellulose and calcium chloride. J. Appl. Oral. Sci. 2017, 25, 680-688. [CrossRef] [PubMed]

141. Perez-Heredia, M.; Clavero-González, J.; Marchena-Rodríguez, L. Use of melatonin in oral health and as dental premedication. J. Biol. Res. (Thessalon) 2015, 22, 13. [CrossRef] [PubMed]

142. Asgary, S.; Parirokh, M.; Eghbal, M.J.; Brink, F. A comparative study of white mineral trioxide aggregate and white Portland cements using X-ray microanalysis. Aust. Endod. J. 2004, 30, 89-92. [CrossRef] [PubMed]

143. Funteas, U.; Wallace, J.A.; Fochtman, E. A comparative analysis of Mineral Trioxide Aggregate and Portland cement. Aust. Endod. J. 2003, 29, 43-44. [CrossRef] [PubMed]

144. Ber, B.S.; Hatton, J.F.; Stewart, G.P. Chemical Modification of ProRoot MTA to Improve Handling Characteristics and Decrease Setting Time. J. Endod. 2007, 33, 1231-1234. [CrossRef] [PubMed]

145. Min, K.-S.; Kim, H.-I.; Park, H.-J.; Pi, S.-H.; Hong, C.-U.; Kim, E.-C. Human Pulp Cells Response to Portland Cement In Vitro. J. Endod. 2007, 33, 163-166. [CrossRef] [PubMed]

146. Oliveira, M.G.d.; Xavier, C.B.; Demarco, F.F.; Pinheiro, A.L.B.; Costa, A.T.; Pozza, D.H. Comparative chemical study of MTA and portland cements. Braz. Dent. J. 2007, 18, 3-7. [CrossRef] [PubMed]

147. Camilleri, J. The chemical composition of mineral trioxide aggregate. J. Conserv. Dent. 2008, 11, 141-143. [CrossRef] [PubMed]

148. Zakerzadeh, A.; Esnaashari, E.; Dadfar, S. In Vitro Comparison of Cytotoxicity and Genotoxicity of Three Vital Pulp Capping Materials. Iran. Endod. J. 2017, 12, 419-425. [CrossRef] [PubMed]

149. Kim, Y.; Lee, D.; Song, D.; Kim, H.M.; Kim, S.Y. Biocompatibility and Bioactivity of Set Direct Pulp Capping Materials on Human Dental Pulp Stem Cells. Materials 2020, 13, 3925. [CrossRef]

150. Poggio, C.; Ceci, M.; Dagna, A.; Beltrami, R.; Colombo, M.; Chiesa, M. In vitro cytotoxicity evaluation of different pulp capping materials: A comparative study. Arh. Hig. Rada Toksikol. 2015, 66, 181-188. [CrossRef]

151. Nowicka, A.; Lipski, M.; Parafiniuk, M.; Sporniak-Tutak, K.; Lichota, D.; Kosierkiewicz, A.; Kaczmarek, W.; BuczkowskaRadlińska, J. Response of Human Dental Pulp Capped with Biodentine and Mineral Trioxide Aggregate. J. Endod. 2013, 39, 743-747. [CrossRef]

152. Luo, Z.; Kohli, M.R.; Yu, Q.; Kim, S.; Qu, T.; He, W.X. Biodentine induces human dental pulp stem cell differentiation through mitogen-activated protein kinase and calcium-/calmodulin-dependent protein kinase II pathways. J. Endod. 2014, 40, 937-942. [CrossRef]

153. Collado-González, M.; García-Bernal, D.; Oñate-Sánchez, R.E.; Ortolani-Seltenerich, P.S.; Álvarez-Muro, T.; Lozano, A.; Forner, L.; Llena, C.; Moraleda, J.M.; Rodríguez-Lozano, F.J. Cytotoxicity and bioactivity of various pulpotomy materials on stem cells from human exfoliated primary teeth. Int. Endod. J. 2017, 50 (Suppl. S2), e19-e30. [CrossRef] [PubMed]

154. Gu, J.; Ikeda, H.; Suda, H. Sympathetic Regulation of Tertiary Dentinogenesis via Beta-2 Adrenergic Receptor on Rat Odontoblasts. J. Endod. 2015, 41, 1056-1060. [CrossRef] [PubMed]

155. Tziafa, C.; Koliniotou-Koumpia, E.; Papadimitriou, S.; Tziafas, D. Dentinogenic Activity of Biodentine in Deep Cavities of Miniature Swine Teeth. J. Endod. 2015, 41, 1161-1166. [CrossRef] [PubMed]

156. De Carvalho, R.V.; Chisini, L.A.; Ferruá, C.P.; Guiraldo, R.D.; Gonini-Júnior, A.; Moura, S.K.; Tarquínio, S.B.; Demarco, F.F. The influence of concentration of HEMA on degree of conversion and cytotoxicity of a dental bonding resin. Minerva Stomatol. 2016, 65, 65-71. [PubMed]

157. Górecka, V.; Suliborski, S.; Biskupski, T. Direct pulp capping with a dentin adhesive resin system in children's permanent teeth after traumatic injuries: Case reports. Quintessence Int. 2000, 31, 241-248.

158. Heitmann, T.; Unterbrink, G. Direct pulp capping with a dentinal adhesive resin system: A pilot study. Quintessence Int. 1995, 26, 765-770. [PubMed]

159. Goldberg, M.; Njeh, A.; Uzunoglu, E. Is Pulp Inflammation a Prerequisite for Pulp Healing and Regeneration? Mediat. Inflamm. 2015, 2015, 347649. [CrossRef] [PubMed] 